Final Technical Report for the DOE Grant Entitled:

\title{
Chemical Stimulation of Engineered Geothermal Systems
}

\section{DE-FG36-04G014295}

Peter Rose ${ }^{1}$, Principal Investigator

Mike Mella ${ }^{1}$, Katie Kovac ${ }^{1}$, Scott Fayer ${ }^{1}$, Tianfu Xu $^{2}$, and Karsten Pruess ${ }^{2}$

${ }^{1}$ Energy and Geoscience Institute at the University of Utah

${ }^{2}$ Lawrence Berkeley National Laboratory 


\section{Table of Contents}

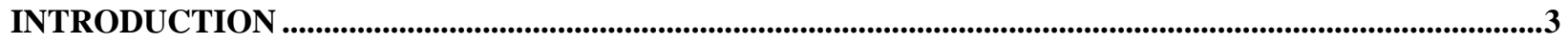

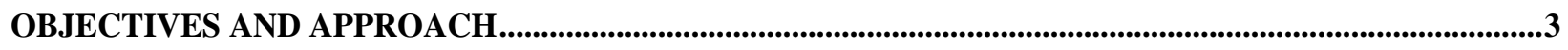

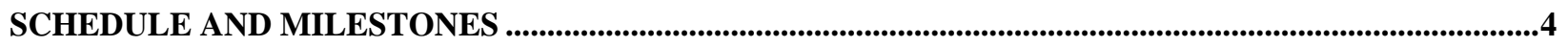

THERMAL STABILITY ANALYSES OF CANDIDATE DISSOLUTION AGENTS ..........................................4

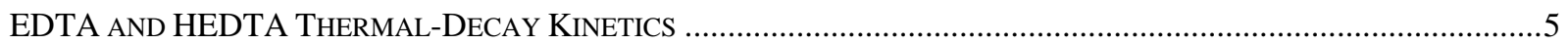

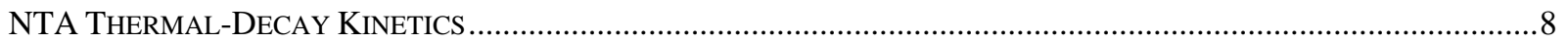

LABORATORY MINERAL-DISSOLUTION EXPERIMENTS USING CANDIDATE REAGENTS...............8

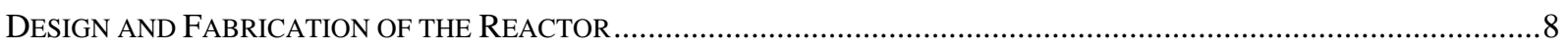

Reactor Design and Fabrication during 2005-2006:....................................................................................

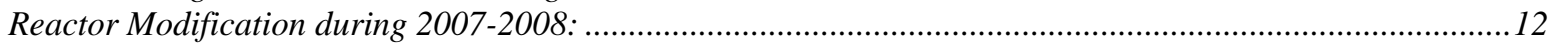

LABORATORY DISSOLUTION EXPERIMENTS CONDUCTED DURING 2006: ............................................................12

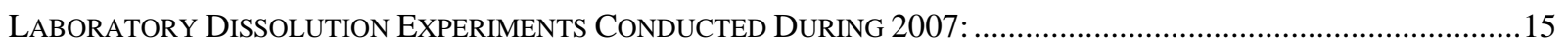

LABORATORY DISSOLUTION EXPERIMENTS CONDUCTED DURING 2008: ..........................................................16

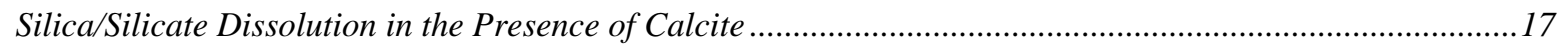

Calcite Dissolution in the Presence of Silica/Silicate .....................................................................................17

FIELD EXPERIMENT .....................................................................................................................................................18

REACTIVE TRANSPORT MODELING OF THE BENCHTOP FLOW REACTOR.......................................22

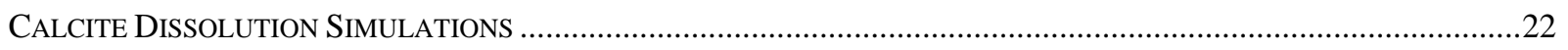

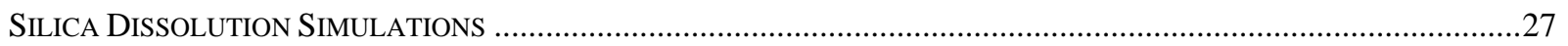

REFERENCES …...................................................................................................................................................29 


\section{Introduction}

In many candidate Engineered Geothermal System (EGS) reservoirs, there is a pre-existing fracture network, but the fractures are impermeable. Minerals have deposited on the fracture walls, blocking the natural flow of fluids through the fractures. The primary objective in the design and development of an EGS is to enhance the permeability of tight-but-hot reservoirs.

An alternative to hydraulic fracturing in the stimulation of Engineered Geothermal Systems is chemical stimulation. In chemical stimulation, minerals are dissolved through the addition of dissolution agents to the circulation fluids. Chemical stimulation works by dissolving minerals within fractures, thereby increasing fracture apertures and enhancing fracture permeability.

By injecting acidic solutions into oil fields at sufficiently high pressures, 'acid fracturing' has been used by the petroleum industry to enhance the effects of hydraulic fracturing. Likewise, the addition of chemical agents capable of dissolving vein minerals would enhance hydraulic fracturing in Engineered Geothermal Systems (EGS). But chemical agents could enhance flow in low permeability EGS reservoirs even if injection pressures and flow rates are too mild to achieve hydraulic fracturing. Thus, chemical agents could provide for a soft stimulation approach that would serve as an alternative to conventional hydraulic stimulation.

In the large majority of geothermal (and, by inference, EGS) reservoirs, the last mineral deposited on fracture surfaces is blocky calcite (Joe Moore, personal communication). Likewise, calcite is often deposited in production wellbores as production fluids flash to steam. Treatment of production wellbores and tight geothermal near-wellbore formations with strong mineral acids is the most commonly employed method of removing these deposited minerals. Due to the high and unpredictable reactivity of strong mineral acids at high temperatures, however, such treatments are risky. The acid tends to dissolve minerals aggressively at the first fluid entry zone that the acid treatment flows through, leaving the larger portion of the wellbore untreated (Paul Spielman, personal communication). In addition, strong acids are especially corrosive towards the carbon steels used in wellbore casings, resulting in much reduced casing life (Bradley, 1989).

\section{Objectives and Approach}

The objective of this project is to design, develop and demonstrate methods for the chemical stimulation of candidate EGS reservoirs as well as the chemical treatment of mineral-scaled wellbores. First, a set of candidate chemical compounds capable of dissolving calcite will be identified. A series of tests will then performed on each candidate in order to screen it for thermal stability and reactivity towards calcite. A detailed analysis will be then performed on each compound that emerges from the screening tests in order to characterize its decay kinetics and reaction kinetics as functions of temperature and chemical composition. From among the compounds emerging from the laboratory studies, one or more compounds will be chosen for field studies in order to verify the laboratory predictions.

The implementation of a chemical approach for stimulating candidate EGS reservoirs may provide a significant cost savings over conventional hydraulic stimulation approaches. Likewise, 
effective and non-corrosive chemical removal of calcite deposits in wellbores and in nearwellbore formations will increase flow rates in both injection and production wells and thereby serve to reduce costs in conventional geothermal-energy processes. Therefore, if successful, this program will help meet the strategic goals of the Geothermal Technologies Program by helping reduce the price of electricity from geothermal sources to 3-5 cents/kWh.

\section{Schedule and Milestones}

The project schedule and milestones are shown in Figure 1. All of the milestones except the final one were met during the first three years of the project. The final milestone was achieved during a 6-month no-cost extension.

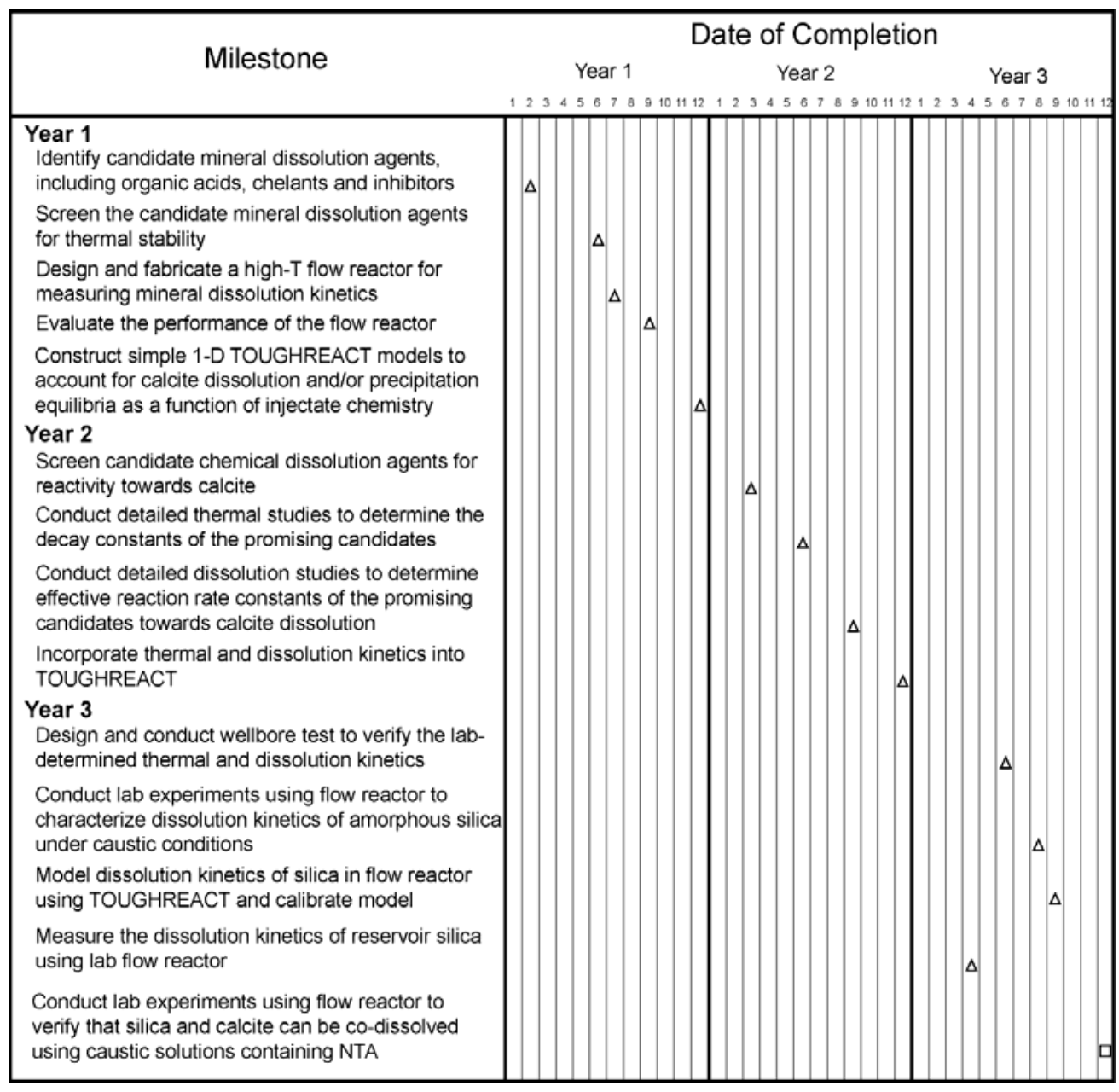

Figure 1. Milestones and expected dates of completion for the chemical stimulation program.

\section{Thermal Stability Analyses of Candidate Dissolution Agents}

Four compounds were selected for testing as candidate dissolution agents including the organic acids acetic acid and benzoic acid and the chelating agents ethylenediaminetetraacetic acid (EDTA) and hydroxyethylene-diaminetetraacetic (HEDTA). Before testing these compounds for 
their dissolution capabilities, however, it was necessary to subject them to thermal stability tests, since the compounds must have sufficient thermal stability to withstand the temperatures of geothermal wellbores and near-wellbore formations. Likewise, in order to conduct these thermal stability tests, it was necessary to develop methods that will allow for their quantitative analysis.

The method selected for the chemical analysis of the candidate dissolution agents was high performance liquid chromatography (HPLC) with either uv or conductivity detection (Waters Corporation, Milford, MA). In order to take advantage of the high-resolution capability of a reverse-phase C-18 column (Keystone BetaBasic-18, 30 mm x 4.6 mm, 3- $\mu \mathrm{m}$ particles), pairedion chromatography (PIC) was employed. The mobile phase consisted of a $\mathrm{pH}-7.5$, phosphate-buffered (3.17 mM Na $2 \mathrm{HPO}_{4} \cdot 7 \mathrm{H}_{2} \mathrm{O}, 6.21 \mathrm{mM}$ anhydrous $\mathrm{KH}_{2} \mathrm{PO}_{4}$ ), $5 \mathrm{mM}$ solution of tetrabutyl ammonium phosphate (TBAP) in various ratios with methanol.

The thermal stabilities of the candidate dissolution agents are being studied using autoclave batch reactors under controlled conditions designed to simulate a geothermal environment. The compounds are first dissolved in aqueous solutions buffered with $0.747 \mathrm{~g} / \mathrm{l}$ of $\mathrm{KH}_{2} \mathrm{PO}_{4}$ and 0.403 $\mathrm{g} / \mathrm{l}$ of $\mathrm{Na}_{2} \mathrm{HPO}_{4}$. Eighteen-ml aliquots of the buffered solutions are then transferred to 30-ml quartz ampules and purged with argon to remove air. The ampules are carefully sealed using an oxymethane flame, while being purged with argon. Oxygen is removed in these initial screening experiments, but the compounds will ultimately be screened in the presence of oxygen, since dissolved oxygen will be present under certain field conditions.

The sealed vials are then transferred to a water-filled, one-liter autoclave (Autoclave Engineers, Philadelphia, PA), which is heated to the target temperature. The time required for the autoclave to attain operational temperature is between 1.5 and 2 hours, whereas the cool-down time is about 4 hours. In all cases, the interior of the reactor is maintained within $1^{\circ} \mathrm{C}$ of the target temperature for the duration of the experiment. The pressure inside the autoclave is the pressure of steam under saturated conditions at the target temperature. The control ampules are stored at $2^{\circ} \mathrm{C}$ for the duration of the autoclave experiments.

\section{EDTA and HEDTA Thermal-Decay Kinetics}

In order to determine the decay kinetics of the candidate dissolution agents EDTA and HEDTA, it was necessary to determine the coefficients of appropriate decay-rate expressions.

Solutions of the candidate chelating agents were transferred glass ampules, which were then sealed while excluding oxygen according to the methods described above. The sealed ampules were themselves sealed in batch reactors and subjected to temperatures between $160^{\circ} \mathrm{C}$ and $180^{\circ} \mathrm{C}$ for durations ranging between 1 and 3 days.

The decay kinetics of the dissolution agents was assumed to obey the following differential equation:

$$
\frac{d C}{d t}=k C^{n}
$$


where $\mathrm{C}$ is concentration, $\mathrm{k}$ is the temperature-dependent decay rate constant and $\mathrm{n}$ is the order of the reaction. In integral form, equation 1 becomes:

$$
\int_{C_{0}}^{C} \frac{d C}{C^{n}}=k \int_{0}^{t} d t
$$

where $\mathrm{C}_{\mathrm{o}}$ is initial concentration.

Solving equation 2 while assuming first-order $(n=1)$ decay kinetics:

$$
\ln \left(C / C_{o}\right)=k t
$$

A plot of equation 3 in Figure 2 reveals a nearly linear fit to the data for the thermal decay of EDTA at a temperature of $160^{\circ} \mathrm{C}$, indicating that the assumption of first-order decay kinetics was valid.

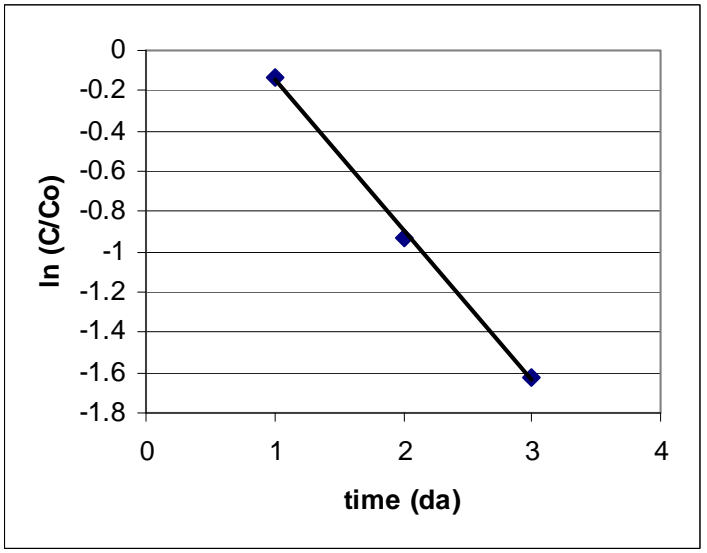

Figure 2. Plot of the first order decay kinetics (equation 3) for EDTA at a temperature of $160^{\circ} \mathrm{C}$.

Likewise, equation 3 is plotted below for the thermal decay of EDTA at $180^{\circ} \mathrm{C}$ :

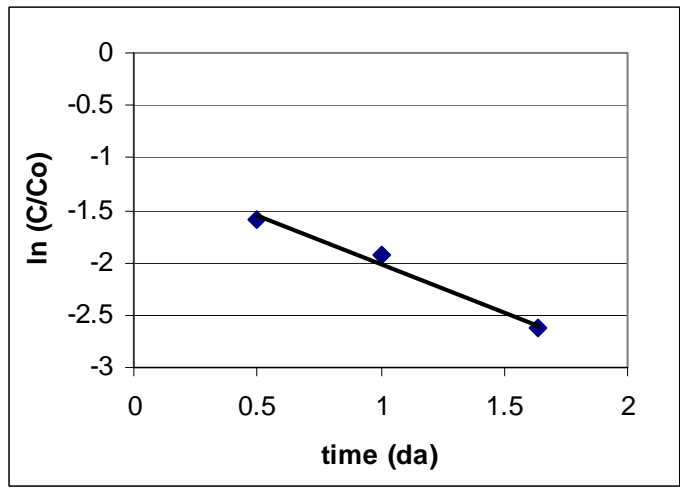

Figure 3. Plot of the first order decay kinetics (equation 3) for EDTA at a temperature of $180^{\circ} \mathrm{C}$. 
A plot of equation 3 in Figure 4 reveals a nearly linear fit to the data for the thermal decay of HEDTA at a temperature of $160^{\circ} \mathrm{C}$, indicating again that the assumption of first-order decay kinetics was valid.

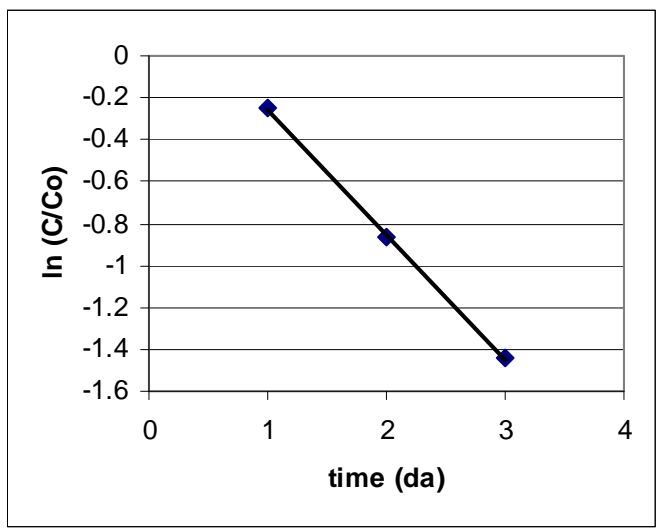

Figure 4. Plot of the first order decay kinetics (equation 3) for HEDTA at a temperature of $160^{\circ} \mathrm{C}$.

Similarly, equation 3 is plotted below for the thermal decay of HEDTA at $180^{\circ} \mathrm{C}$ :

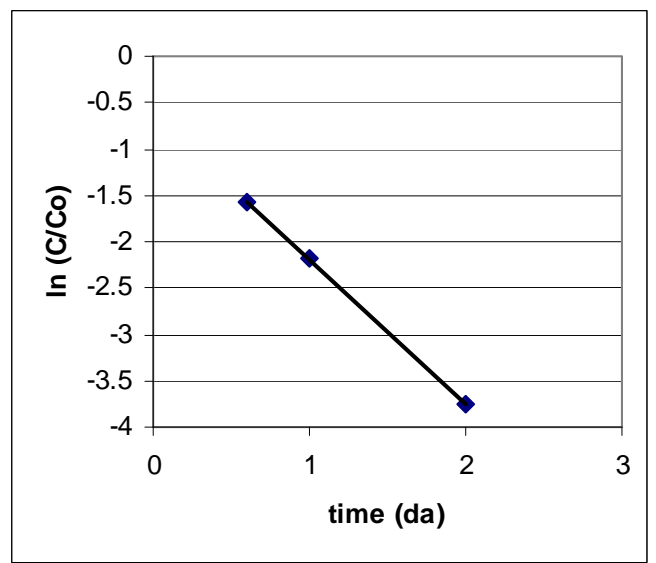

Figure 5. Plot of the first order decay kinetics (equation 3) for HEDTA at a temperature of $180^{\circ} \mathrm{C}$.

The Arrhenius expression provides a convenient mechanism for characterizing the temperature dependence of the decay rate constant:

$$
k=A e^{-E_{a} / R T}
$$

A linearization of equation 4 yields:

$$
\ln k=\ln A-\frac{E_{a}}{R T}
$$


Based upon the data obtained and plotted, the Arrhenius equation for EDTA becomes:

$$
\ln k=4.61-\frac{2,120}{T} \ldots \ldots \ldots \ldots \ldots \ldots(6)
$$

and the Arrhenius equation for HEDTA becomes:

$$
\ln k=21.2-\frac{9,420}{T}
$$

Plots of equation 5 for the thermal decay of EDTA and HEDTA are shown in Figure 6.

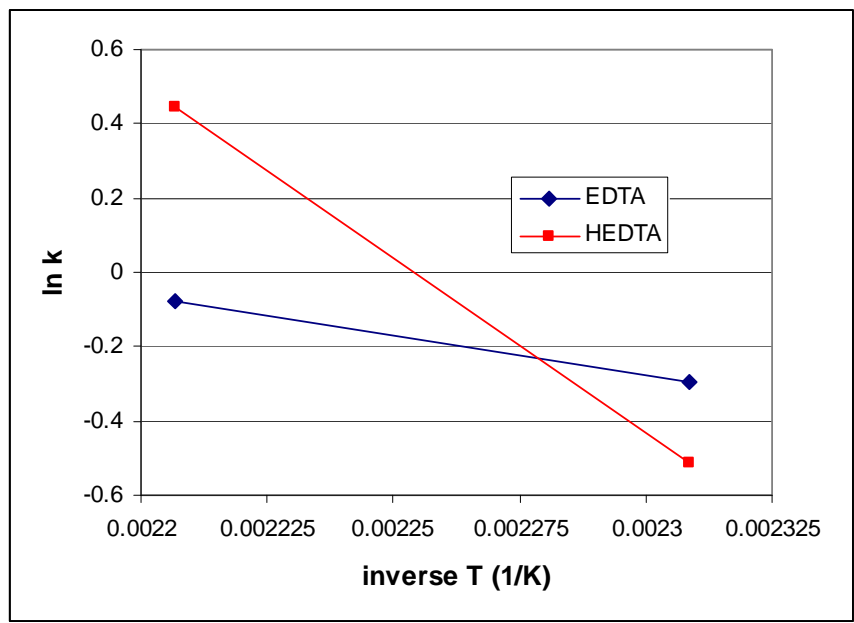

Figure 6. Plots of equations 6 and 7 between the temperatures of $160^{\circ} \mathrm{C}$ and $180^{\circ} \mathrm{C}$.

From these experiments, it was determined that neither compound is sufficiently stable to be useful at reservoir temperatures above about $200^{\circ} \mathrm{C}$.

\section{$\underline{\text { NTA Thermal-Decay Kinetics }}$}

Martell et al (1975) studied the thermal decay kinetics of nitrilotriacetate (NTA) using n.m.r. in experiments at $\mathrm{pH} 9.5$ and temperatures of $260^{\circ} \mathrm{C}$ and $293^{\circ} \mathrm{C}$. They report that NTA was stable at $260^{\circ} \mathrm{C}$ but decomposed starting at $290^{\circ} \mathrm{C}$. Thus, thermal decay kinetics studies were not conducted, since NTA was considered to be sufficiently stable for most geothermal/EGS applications. Due to its superior thermal stability, it was carried into subsequent phases of mineral dissolution testing.

\section{Laboratory Mineral-Dissolution Experiments Using Candidate Reagents}

\section{$\underline{\text { Design and Fabrication of the Reactor }}$}




\section{Reactor Design and Fabrication during 2005-2006:}

A bench-scale laboratory reactor was designed for the purpose of evaluating the performance of candidate reagents for the dissolution of minerals in wellbores and in near-wellbore formations under simulated geothermal conditions. Shown in Figure 7 is a schematic of that design.

Shown as fabricated in the photograph in Figure 8, the reactor assembly consists of an HPLC pump, a preheater, the stainless steel reaction vessel, a chiller that cools the solution after it has passed through the reaction vessel, an inline back pressure regulator, and a bottle for solvent collection.

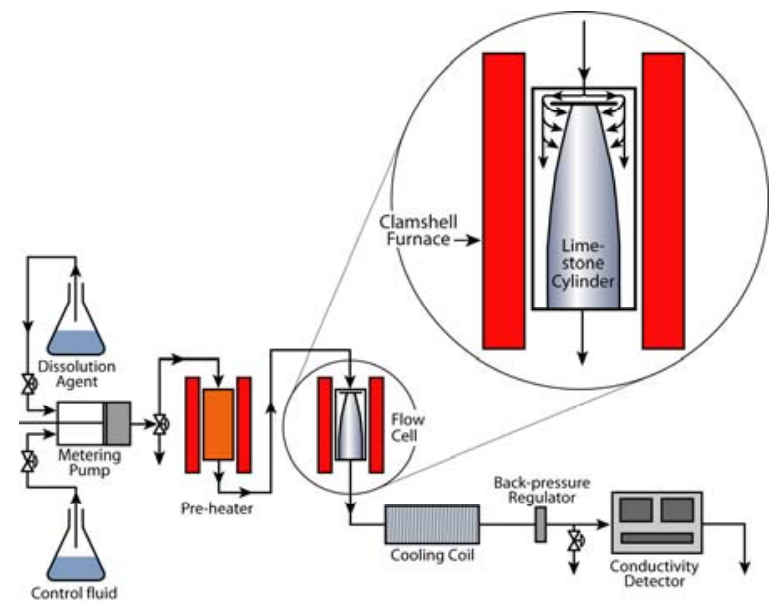

Figure 7. Schematic drawing of the high-temperature flow reactor.

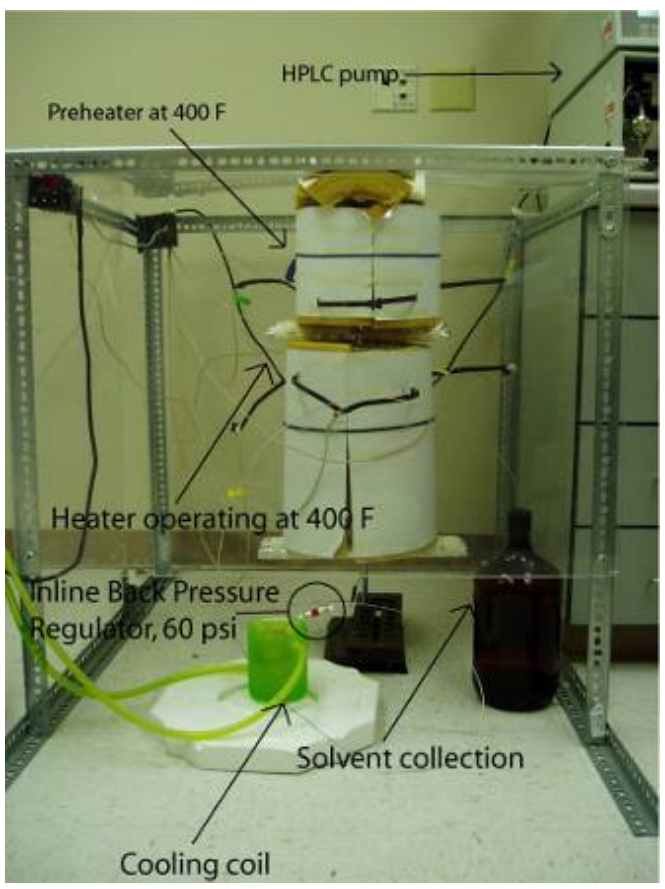

Figure 8. Photograph of the mineral dissolution reactor. 
In order to create a relatively uniform reaction volume of calcite, cylinders were cut from a block of Texas limestone using a 1" diameter coring bit. A picture of the resultant cylinder is shown in Figure 9.

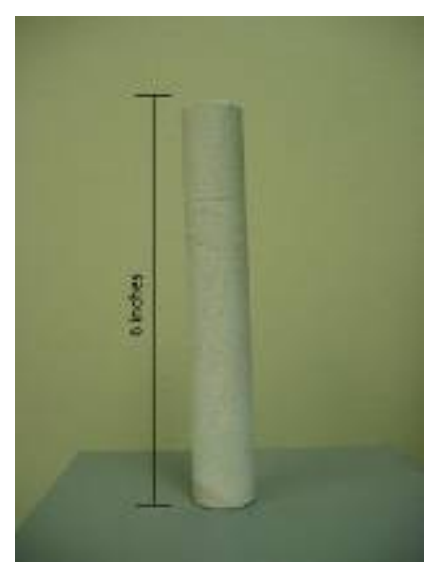

Figure 9. Photograph of the limestone core.

In order to ensure reproducibility, a procedure was developed for handling the limestone cylinders before and after subjecting them to the dissolution experiments. Initially, the limestone core was dried for a minimum of 2 hours in a drying oven at $110^{\circ} \mathrm{C}$; the core weight was then recorded. In order to determine a minimum drying time several cores were weighed dry then soaked in water and then placed in a drying oven for various durations of time. The minimum drying time was found to be a little over 1 hour. Therefore, as a precaution, at least 2 hours of drying time was used to ensure complete dryness.

At the completion of each run the core was removed from the reactor and rinsed with deionized water. The core was then placed in the drying oven for a minimum of 2 hours, removed and weighed again.

A schematic drawing of the high-temperature flow reactor is shown in Figure 7. The design and fabrication of this reactor has been previously described (Mella et al., 2006).

As shown in Figure 7, the flow-reactor was originally designed to allow for the reactant to flow over the surface of a limestone core, with diffusion into and out of the core. But most of the reactant volume simply flowed over the core without making intimate contact with the limestone. Modifications were therefore made to the reactor design to force the reactant solution through the core's pore space. This was achieved by cementing the core to the inside of the reactor cell using a high-temperature silicon adhesive.

To investigate flow patterns through the newly redesigned dissolution reactor, several tests were carried out using real-time tracer detection. In each test, $25 \mu \mathrm{L}$ of a 100 -ppm fluorescein solution was injected into the reactor as a slug via a sample loop. Helium-sparged deionized water was used as the carrier fluid to force the tracer slug through the limestone core. A fluorescence detector was connected after the back pressure regulator and the tracer data were recorded on a 
computer in real time. The data from each experiment were plotted as tracer response versus time. Each test was repeated several times to ensure quality.

In the first experiment, the reactor was loaded with an uncemented limestone core and maintained at a temperature of $24^{\circ} \mathrm{C}$ as water with the tracer slug was allowed to flow through it at a rate of $1 \mathrm{ml} / \mathrm{min}$. The core has a diameter of 0.995 inches and the reactor has an internal diameter of 1.01 inches. From the shape of the tracer response in Figure 10, the flow was assumed to pass almost exclusively around the core within the 0.015 inches of clearance between the core and the reactor, with some undetermined amount of diffusion into and out of the core and/or dispersion through the relatively stagnant regions of the reactor.

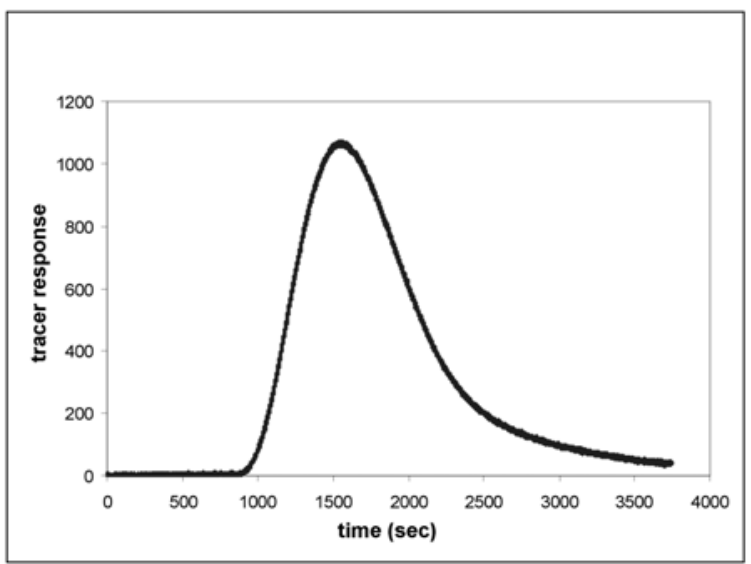

Figure 10. Tracer response in a test of the flow reactor at $24^{\circ} \mathrm{C}$ and $1 \mathrm{ml} / \mathrm{min}$ when an uncemented core was present.

In the subsequent experiment, the reactor/core assembly was modified in order to inhibit flow between the limestone core and the inner surface of the reactor, thus forcing the flow through the pore space within the core. In these experiments the limestone core was covered with a hightemperature/high-strength silicone adhesive before sliding it into the reactor. The adhesive was allowed to cure overnight at a temperature of $90^{\circ} \mathrm{F}$.

The tracer experiment was then repeated (see Figure 11). A maximum-tracer response was observed at approximately the same time, but with much lower resolution and with the tracer appearing to be produced in pulses, indicating multiple channeling through the limestone core. 


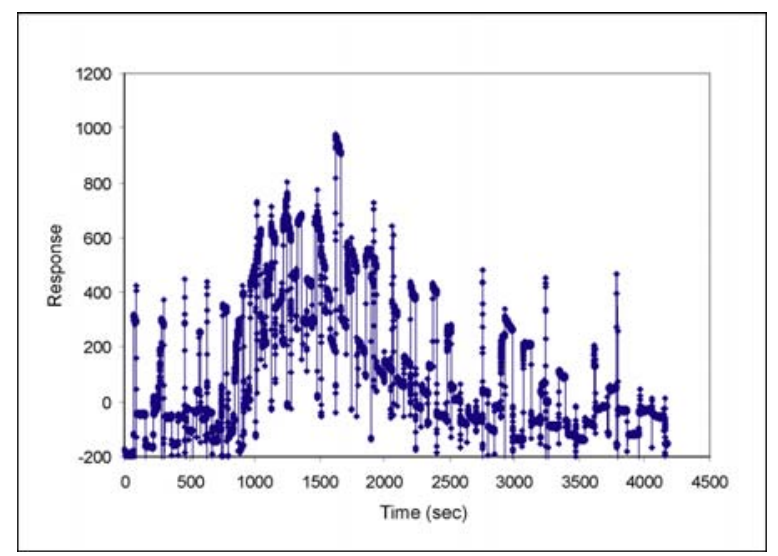

Figure 11. Tracer response in a flow test of the reactor at $24^{\circ} \mathrm{C}$ and $1 \mathrm{ml} / \mathrm{min}$ when the limestone core was bonded to the interior of the reactor.

Reactor Modification during 2007-2008:

The flow reactor was modified to allow for a second thermocouple that is placed at the inlet of the heated flow cell. This is in addition to the primary thermocouple that touches the outside of the stainless steel flow cell and that serves as a reference point for the furnace controller. This modification allows for a much more accurate reading of the temperature within the flow cell.

\section{Laboratory Dissolution Experiments Conducted During 2006:}

Using the procedure described in the section above, several experiments were conducted. The limestone cylinders were subjected to reaction conditions of $\mathrm{pH} 4$ to 12 with temperatures as high as $250^{\circ} \mathrm{C}$. From these experiments it was shown that NTA at neutral pH dissolved the limestone cores as well or better than any other combination of reagents and $\mathrm{pH}$ 's. At higher $\mathrm{pH}$, however, the dissolution is negative, indicating the possible trapping of reagent or mineral deposition within the sample pore space.

The experimental procedure described was used to conduct the laboratory dissolution experiments. Shown in Table 1 is a listing of the dissolution agents studied to date and the experimental conditions. 
Table 1. Reaction conditions and results from recent experiments using the limestone core flow reactor.

\begin{tabular}{|c|c|c|c|c|c|c|c|}
\hline $\begin{array}{l}\text { Time } \\
\text { (hrs.) }\end{array}$ & $\begin{array}{l}\text { flow rate } \\
\text { (ml/min) }\end{array}$ & temp $(F)$ & temp (C) & $\begin{array}{c}\text { weight } \\
\text { change (g) }\end{array}$ & solvent & $\mathrm{pH}$ & $\begin{array}{c}\text { g(dissolved)l } \\
\text { ml(flowed) } x \\
10^{4} \\
\end{array}$ \\
\hline 5.25 & 0.5 & 70 & 21.1 & 0.04 & DI water & 7 & 2.54 \\
\hline 5.25 & 0.5 & 212 & 100.0 & 0 & DI water & 7 & 0.00 \\
\hline 6.25 & 0.5 & 300 & 148.9 & 0 & DI water & 7 & 0.00 \\
\hline 6 & 0.5 & 400 & 204.4 & 0.03 & DI water & 7 & 1.67 \\
\hline 5.25 & 1 & 317 & 158.3 & 0.002 & DI water & 7 & 0.06 \\
\hline 5 & 1 & 75 & 23.9 & 0.01 & DI water & 7 & 0.33 \\
\hline 3 & 1 & 482 & 250.0 & 0.017 & DI water & 7 & 0.96 \\
\hline 6.5 & 1 & 72 & 22.2 & 0.08 & $\mathrm{HCl}$ & 4 & 2.05 \\
\hline 8.5 & 1 & 215 & 101.7 & 0.09 & $\mathrm{HCl}$ & 4 & 1.76 \\
\hline 9.25 & 1 & 300 & 148.9 & 0.13 & $\mathrm{HCl}$ & 4 & 2.34 \\
\hline 3.75 & 1 & 480 & 248.9 & 0.029 & $\mathrm{HCl}$ & 4 & 1.27 \\
\hline 3.5 & 1 & 403 & 206.1 & 0.055 & $\mathrm{HCl}$ & 4 & 2.61 \\
\hline 9 & 1 & 72 & 22.2 & 0.04 & EDTA (37.2 ppm) & 7 & 0.74 \\
\hline 7.5 & 1 & 219 & 103.9 & 0.06 & EDTA (37.2 ppm) & 7 & 1.33 \\
\hline 8.5 & 1 & 321 & 160.6 & 0.03 & EDTA (37.2 ppm) & 7 & 0.59 \\
\hline 8.25 & 1 & 400 & 204.4 & 0.05 & EDTA (37.2 ppm) & 7 & 1.01 \\
\hline 4.25 & 1 & 480 & 248.9 & 0.066 & EDTA (37.2 ppm) & 7 & 2.58 \\
\hline 1.5 & 1 & 482 & 250.0 & 0.22 & EDTA (3.72\%) 0.1M & 7 & 24.44 \\
\hline 6.5 & 1 & 72 & 22.2 & 0.01 & EDTA (37.2 ppm) & 12 & 0.26 \\
\hline 7 & 1 & 318 & 158.9 & 0.094 & EDTA (37.2 ppm) & 12 & 2.23 \\
\hline 5.25 & 1 & 472 & 244.4 & -0.023 & EDTA (37.2 ppm) & 12 & -0.73 \\
\hline 5.25 & 1 & 393 & 200.6 & 0.034 & EDTA (37.2 ppm) & 12 & 1.06 \\
\hline 4.5 & 1 & 225 & 107.2 & 0.061 & NTA (19.12 ppm) & 12 & 2.24 \\
\hline 5.5 & 1 & 400 & 204.4 & 0.004 & NTA (19.12 ppm) & 12 & 0.11 \\
\hline 2 & 1 & 409 & 209.4 & 0.032 & NTA (38 ppm) & 7 & 2.68 \\
\hline 5 & 1 & 317 & 158.3 & 0.068 & NTA (38 ppm) & 7 & 2.28 \\
\hline 4 & 1 & 221 & 105.0 & 0.03 & NTA (38 ppm) & 7 & 1.25 \\
\hline 4 & 1 & 415 & 212.8 & -0.04 & NTA (19.2 ppm) & 12 & -1.66 \\
\hline 2.5 & 1 & 480 & 248.9 & 0.05 & NTA (38 ppm) & 7 & 3.30 \\
\hline 3.42 & 1 & 70 & 21.1 & 0.022 & NTA (38 ppm) & 7 & 1.05 \\
\hline 3 & 1 & 403 & 206.1 & -0.008 & $\mathrm{NaOH}$ & 12 & -0.47 \\
\hline 2.5 & 1 & 482 & 250.0 & -0.007 & $\mathrm{NaOH}$ & 12 & -0.47 \\
\hline 2 & 1 & 72 & 22.2 & 0.006 & $\mathrm{NaOH}$ & 12 & 0.50 \\
\hline 3 & 1 & 217 & 102.8 & 0.01 & $\mathrm{NaOH}$ & 12 & 0.54 \\
\hline 0.5 & 1 & 474 & 245.6 & 0.64 & NTA $10 \%$ & 7 & 213.47 \\
\hline 3 & 1 & 475 & 246.1 & 0.086 & NTA $1 \%$ & 7 & 4.76 \\
\hline 2 & 1 & 391 & 199.4 & 0.249 & NTA $1 \%$ & 7 & 20.71 \\
\hline 2.25 & 1 & 295 & 146.1 & 0.25 & NTA $1 \%$ & 7 & 18.50 \\
\hline 2.25 & 1 & 482 & 250.0 & 0.185 & NTA 1000 ppm & 10 & 13.70 \\
\hline
\end{tabular}


Some of the data were plotted as grams of core dissolved per milliliter of solvent flowed versus temperature (see Figure 12).

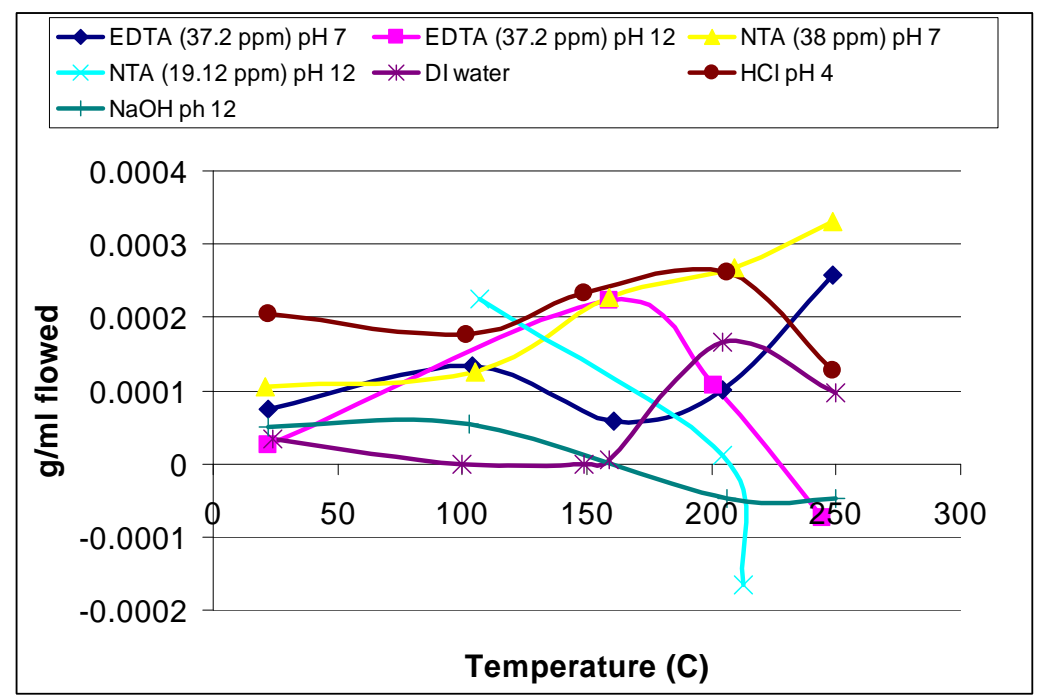

Figure 12. A plot showing the mass of core dissolved per volume of solvent flowed versus temperature in ${ }^{\circ} \mathrm{C}$ for the various dissolution reagents.

In addition to the low-flow-rate tests shown above, experiments at a flow rate of $5.0 \mathrm{ml} / \mathrm{min}$ were also conducted. The results of the $5.0 \mathrm{ml} / \mathrm{min}$ tests are summarized below in Table 2 . 
Table 2. Reaction conditions and results from recent experiments using the limestone core flow reactor at $5 \mathrm{ml} / \mathrm{min}$ flow rate.

\begin{tabular}{|c|c|c|c|c|c|c|c|}
\hline $\begin{array}{l}\text { Time } \\
\text { (hrs.) }\end{array}$ & $\begin{array}{c}\text { flow } \\
\text { rate } \\
\text { (ml/min) }\end{array}$ & $\begin{array}{c}\text { temp } \\
(F)\end{array}$ & temp (C) & $\begin{array}{c}\text { weight } \\
\text { change (g) }\end{array}$ & solvent & $\mathrm{pH}$ & $\begin{array}{c}\text { g(dissolved) } / \\
\mathrm{ml}(\text { flowed }) \times 10^{4}\end{array}$ \\
\hline 2.5 & 5 & 70 & 21.1 & 0.001 & DI water & 7 & 0.01 \\
\hline 2 & 5 & 482 & 250.0 & 0.120 & DI water & 7 & 2.01 \\
\hline 2 & 5 & 305 & 151.7 & 0.044 & DI water & 7 & 0.74 \\
\hline 2 & 5 & 72 & 22.2 & 0.001 & NTA (38.2 ppm) & 12 & 0.02 \\
\hline 2 & 5 & 482 & 250.0 & 0.176 & NTA (200 ppm) & 7 & 2.92 \\
\hline 2 & 5 & 399 & 203.9 & 0.154 & NTA (200 ppm) & 7 & 2.57 \\
\hline 2 & 5 & 291 & 143.9 & 0.239 & NTA (200 ppm) & 7 & 3.98 \\
\hline 1.75 & 5 & 72 & 22.2 & 0.142 & NTA (200 ppm) & 7 & 2.70 \\
\hline 2 & 5 & 72 & 22.2 & 0.074 & NTA (200 ppm) & 10 & 1.24 \\
\hline 2 & 5 & 302 & 150.0 & 0.119 & NTA (200 ppm) & 10 & 1.98 \\
\hline 2 & 5 & 482 & 250.0 & 0.151 & NTA (200 ppm) & 10 & 2.51 \\
\hline 2 & 5 & 480 & 248.9 & 0.097 & NTA (38.2 ppm) & 7 & 1.62 \\
\hline 2 & 5 & 302 & 150.0 & 0.061 & NTA (38.2 ppm) & 7 & 1.02 \\
\hline 2.167 & 5 & 72 & 22.2 & 0.042 & $\mathrm{HCl}$ & 4 & 0.65 \\
\hline 2.333 & 5 & 482 & 250.0 & 0.078 & $\mathrm{HCl}$ & 4 & 1.12 \\
\hline 2 & 5 & 300 & 148.9 & 0.066 & $\mathrm{HCl}$ & 4 & 1.10 \\
\hline
\end{tabular}

The data were plotted as gram dissolved per milliliter flowed versus temperature (see Figure 13).

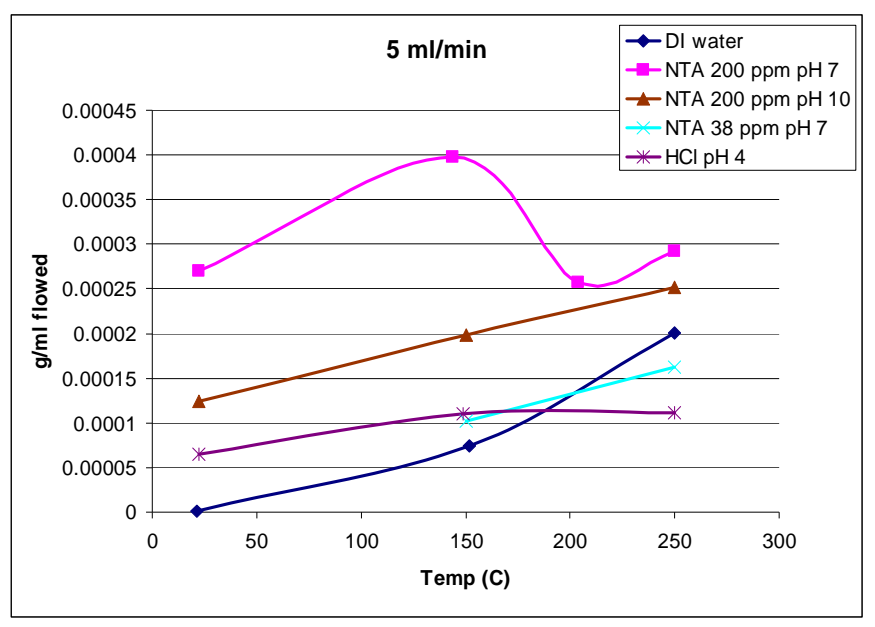

Figure 13. Plot showing the relative dissolution of the limestone core using various dissolution agents at a flow rate of $5 \mathrm{ml} / \mathrm{min}$.

At the higher flow rate, the inconsistencies due possibly to the deposition effect observed at the lower flow rate and the higher temperatures seem to have been eliminated.

Laboratory Dissolution Experiments Conducted During 2007: 
A study of silica dissolution at high temperature and high $\mathrm{pH}$ was initiated using the flow reactor shown in Figure 7. The limestone rod was replaced with 6-mm glass beads, which served as a proxy for amorphous silica. The temperature ranged between $150^{\circ} \mathrm{C}$ and $300^{\circ} \mathrm{C}$ and the flow rate was $10 \mathrm{ml} / \mathrm{min}$. The injection water had a pH of 14, which was achieved by adding $\mathrm{NaOH}$. Shown in Figure 14 is a plot of silica dissolution as a function of temperature under these conditions.

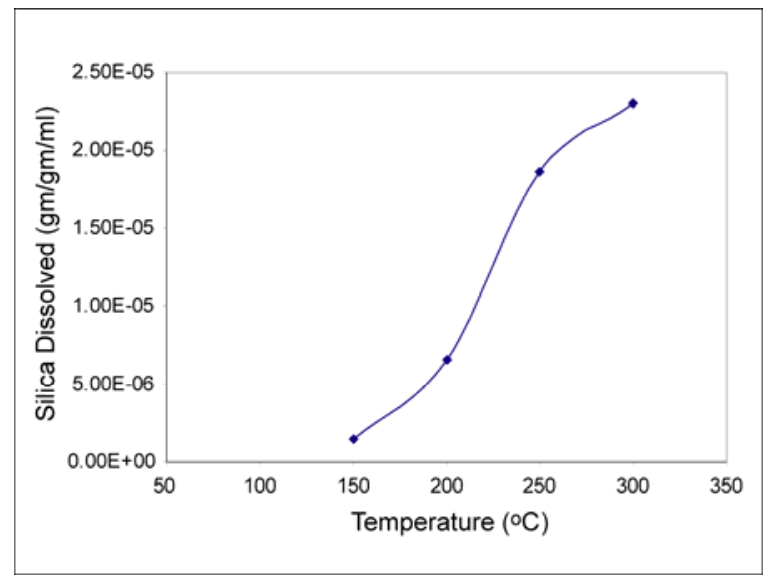

Figure 14. Total silica dissolution in the flow reactor at $p H 14$ between $150^{\circ} \mathrm{C}$ and $300^{\circ} \mathrm{C}$. Each point on the curve shows the mass of silica dissolved divided by the initial mass and the total solution volume that flowed through the reactor during a 2-hour period.

Laboratory Dissolution Experiments Conducted During 2008:

A study of the simultaneous dissolution of calcite and silica/silicate was conducted using the modified flow reactor described above. In a typical experiment, the flow cell was charged with particles of calcite overlaying glass beads (representing sodium silicate), particles of amorphous silica or particles of quartz. In all cases, the particles were sized to be less than $9.3 \mathrm{~mm}$ and greater than $3.9 \mathrm{~mm}$. The glass beads were $6 \mathrm{~mm}$ in diameter. A cross-sectional drawing (not to scale) of the charged flow cell is shown in Figure 15.

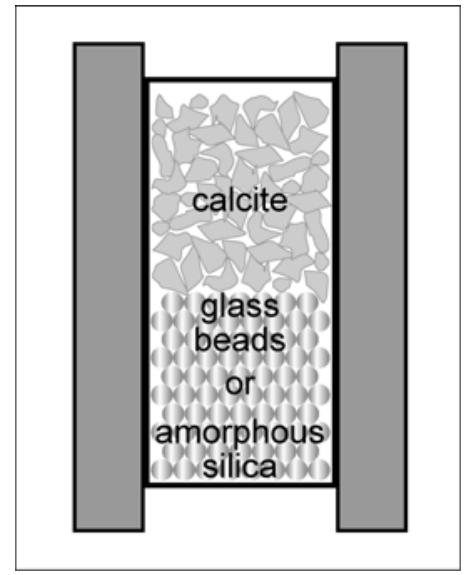

Figure 15. Cross-sectional drawing (not to scale) of the reactor flow cell. 
In all cases, the solution consisted of $0.1 \mathrm{M}$ nitrilotriacetate (NTA) and $0.1 \mathrm{M}$ citrate at $\mathrm{pH} 12.5$. The reactor was charged with a sufficient mineral volume to fill the flow cell. The pump was set at a flow rate of $2.0 \mathrm{ml} / \mathrm{min}$ and the furnace was switched on allowing the flow cell to heat rapidly to the target temperature. The set temperatures ranged between $160^{\circ} \mathrm{C}$ and $280^{\circ} \mathrm{C}$ with sufficient pressure to keep the solution in the liquid phase. Typically, each reaction was run for a duration of 4 hours. After the run, the cell was allowed to cool and the reacted minerals were dried and weighed.

\section{$\underline{\text { Silica/Silicate Dissolution in the Presence of Calcite }}$}

Shown in Figure 16 below is a plot of silica and sodium-aluminum-calcium silicate (as glass beads) in the presence of calcite chips, showing increased mineral dissolution at higher temperatures. It is evident that silica was dissolving at a greater rate than silicate, but there was no attempt to control for surface area. Therefore, differences in dissolution rate could be explained, at least in part, by differences in surface area and porosity between the silica and silicate-mineral samples.

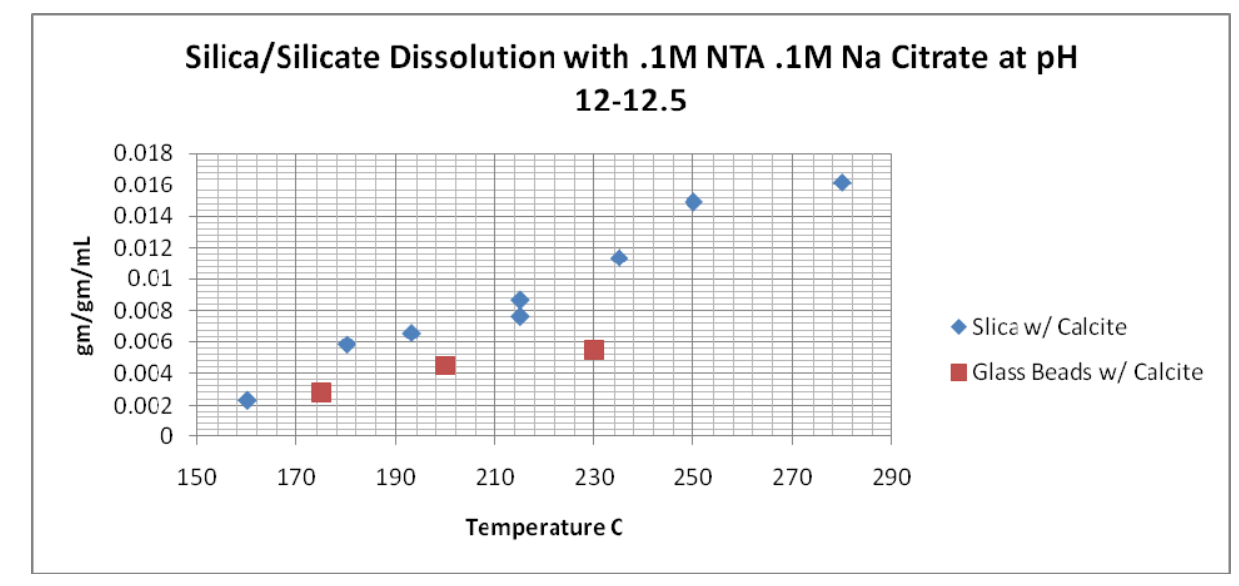

Figure 16. Silica/silicate dissolution in the presence of calcite between $160^{\circ} \mathrm{C}$ and $280^{\circ} \mathrm{C}$. Each point on the curve shows the mass of silica or silicate dissolved divided by the initial mass and the total solution volume that flowed through the reactor during the experiment.

\section{Calcite Dissolution in the Presence of Silica/Silicate}

Just as silica/silicate was shown to dissolve in the presence of calcite, Figure 17 shows that calcite, itself, dissolves in the presence of silica/silicate in an NTA solution at high pH and high temperature. Such conditions of high $\mathrm{pH}$ normally promote calcite precipitation, but in the presence of the chelating agent, there is a net dissolution of calcite. Thus, the combination of NTA and citrate at high $\mathrm{pH}$ can serve as a viable dissolution agent for dissolving both silica/silicate and calcite. This mixture of reagents provides an affordable alternative to the use of hydrofluoric acid for dissolving silica/silicate in wellbores and in near-wellbore formations in geothermal reservoirs. 


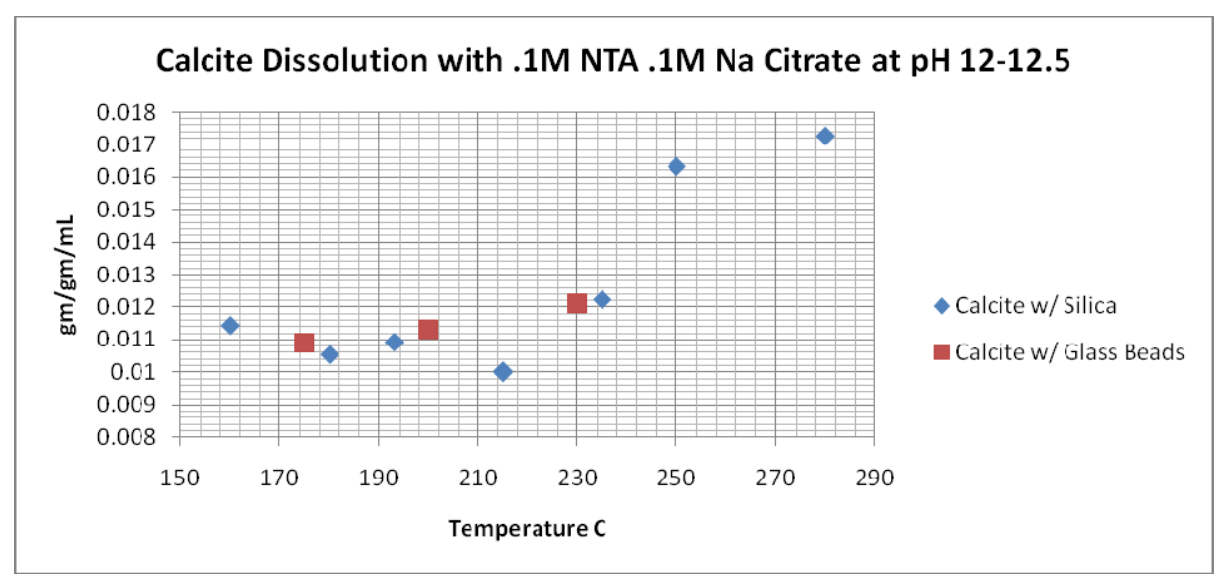

Figure 17. Calcite dissolution in the presence of silica/silicate between $160^{\circ} \mathrm{C}$ and $280^{\circ} \mathrm{C}$. Each point on the curve shows the mass of calcite dissolved divided by the initial mass and the total solution volume that flowed through the reactor during the experiment.

\section{Field Experiment}

The most promising mineral dissolution agent to emerge from the laboratory studies was the chelating agent nitrilotriacetate (NTA). Although our thermal stability studies have not been completed, the literature suggested that NTA could be used at temperatures as high as $290^{\circ} \mathrm{C}$, whereas the other two chelating agents, EDTA and HEDTA, were significantly less thermally stable with maximum use temperatures in the range of $200^{\circ} \mathrm{C}$.

The calcite dissolution experiments in the high temperature flow reactor confirmed the superior performance of NTA above $200^{\circ} \mathrm{C}$. Therefore, a field experiment was designed for dissolving calcite in a wellbore at the Coso field.

The well that was selected was producer 32A-20, which had recently failed due to calcite deposition. On June 16, 15,000 gal of a $10 \mathrm{wt} \%$ solution of NTA was injected into the well in a series of three 5,000-gal injections. The solutions were each injected at 5-6 bbl/min at intervals shown in Figure 18. The total volume of fluid injected (15,000 gal) was calculated to be approximately the volume of the open-hole section of the well. 


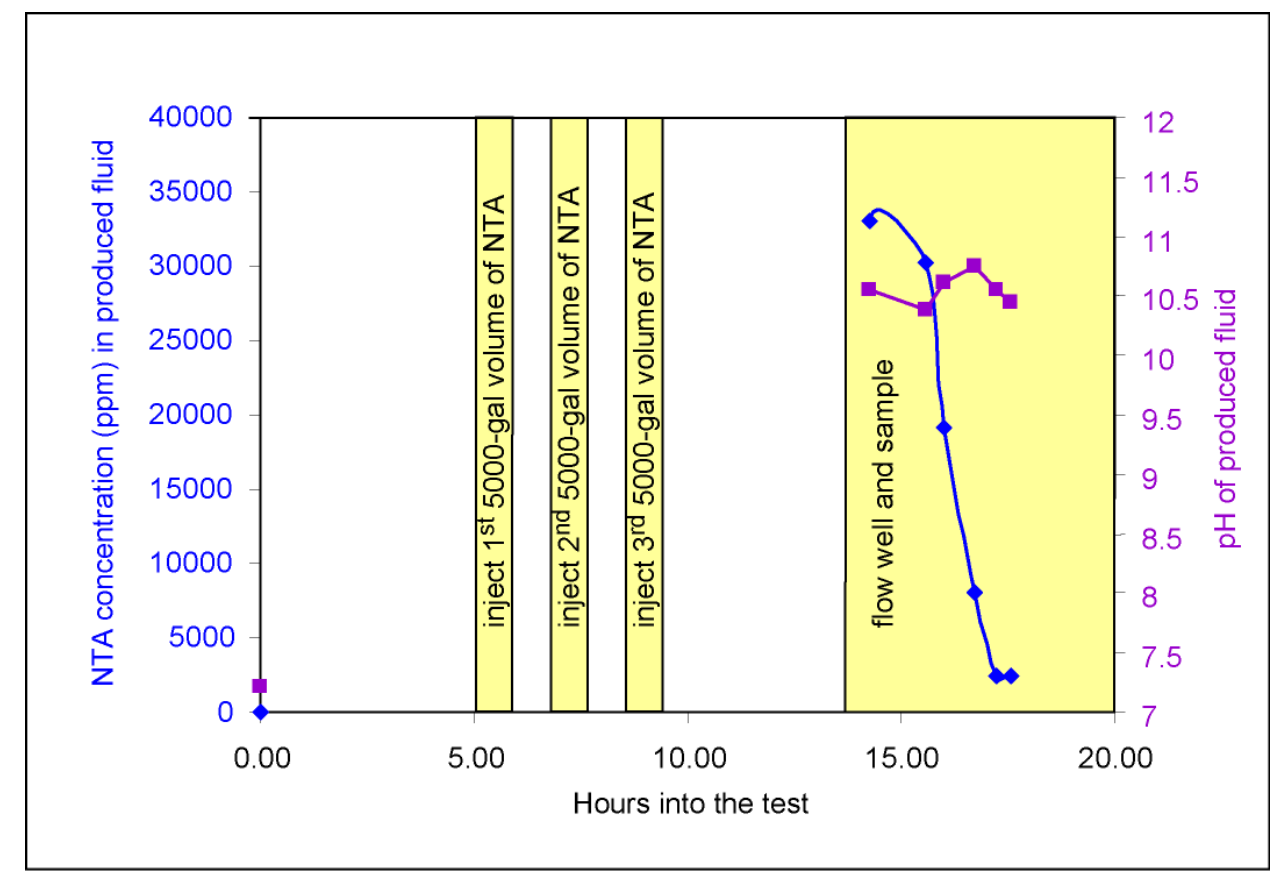

Figure 18. Summary of the chemical stimulation experiment of production well 32A-20 showing the injection of three 5,000-gal slugs of $10 \mathrm{wt} \%$ NTA followed by a 4-hr shut-in, followed by the production of the well to the 32-20 pit. The plots in blue and purple show the concentration of the uncomplexed NTA and the $\mathrm{pH}$ of the produced solutions, respectively.

Upon completion of the injection of the NTA solution, the well was shut in for approximately four hours, giving the chelating agent time to dissolve the calcite scale. At approximately 8 PM, the well was opened, allowing brine to flow to the 32-20 pit. At first the brine was clear, but soon turned to milky white, indicating the presence of the calcium-NTA complex (see Figure 19). Plotted in Figure 18 is the concentration of the unreacted NTA showing that its concentration dropped from about 34,000 ppm to approximately 2,000 ppm during the experiment. The final value of 2,000 ppm indicated that the milky white NTA solution being produced was nearly completely complexed with calcium. 


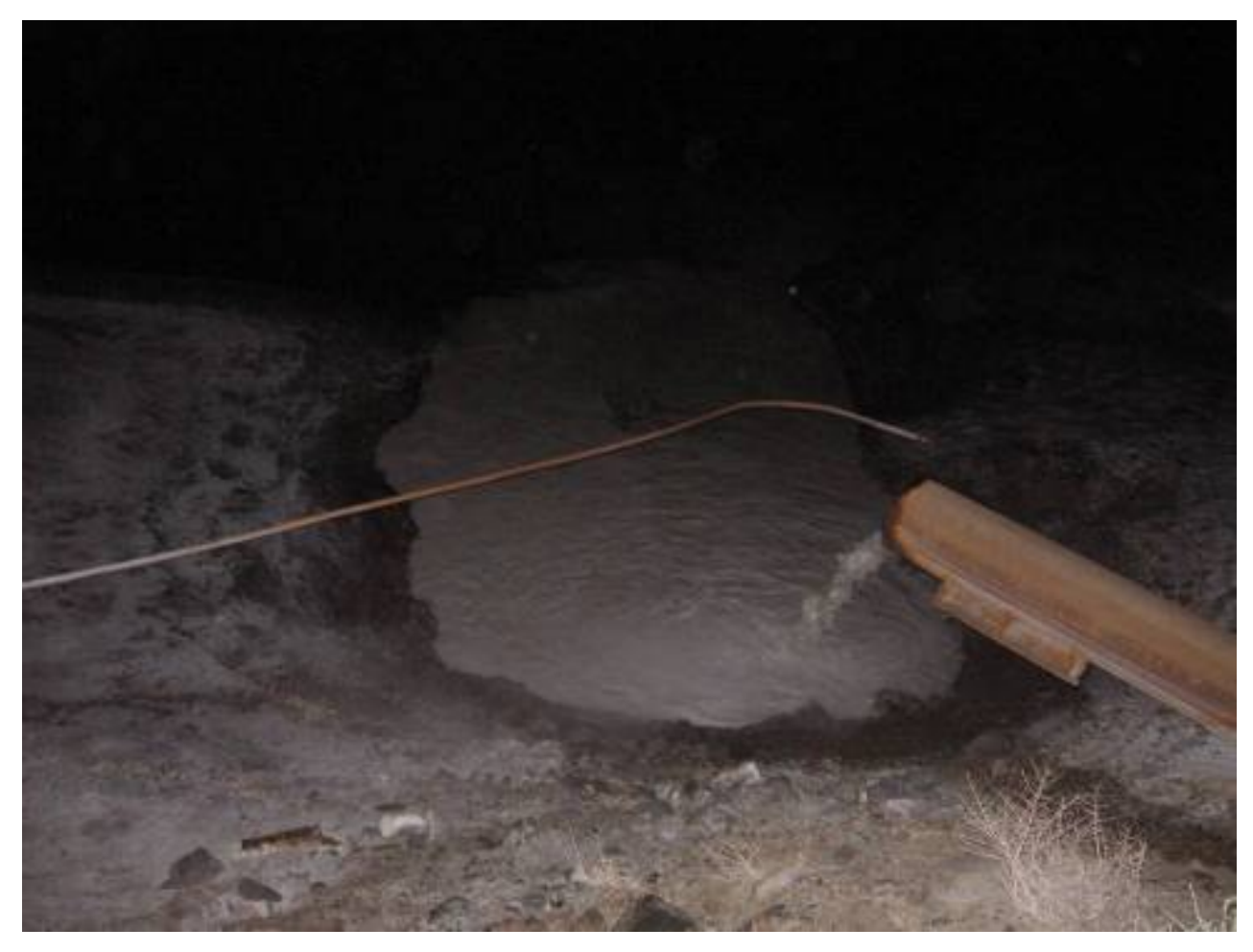

Figure 19. Picture of the produced fluid from 32A-20 to the adjacent pit about 3 hours after the well was opened. Note the milky-white color of the produced fluid indicating the calciumNTA complex.

The well 32A-20 was soon put on line for the generation of electricity. Shown in Figure 20 is a plot of the electrical output of 32A-20 between February and April, 2006 at approximately 1.4 MWe and the restoration of electrical output of 32A-20 to nearly that level after the injection of the NTA chelating agent. These experiments indicate that NTA can be an effective dissolution agent for the dissolution of wellbore calcite. The production of unreacted NTA (Figure 11) early in the production cycle indicates that a longer shut-in period may have resulted in a more complete reaction of the NTA solution and more wellbore calcite dissolution. 


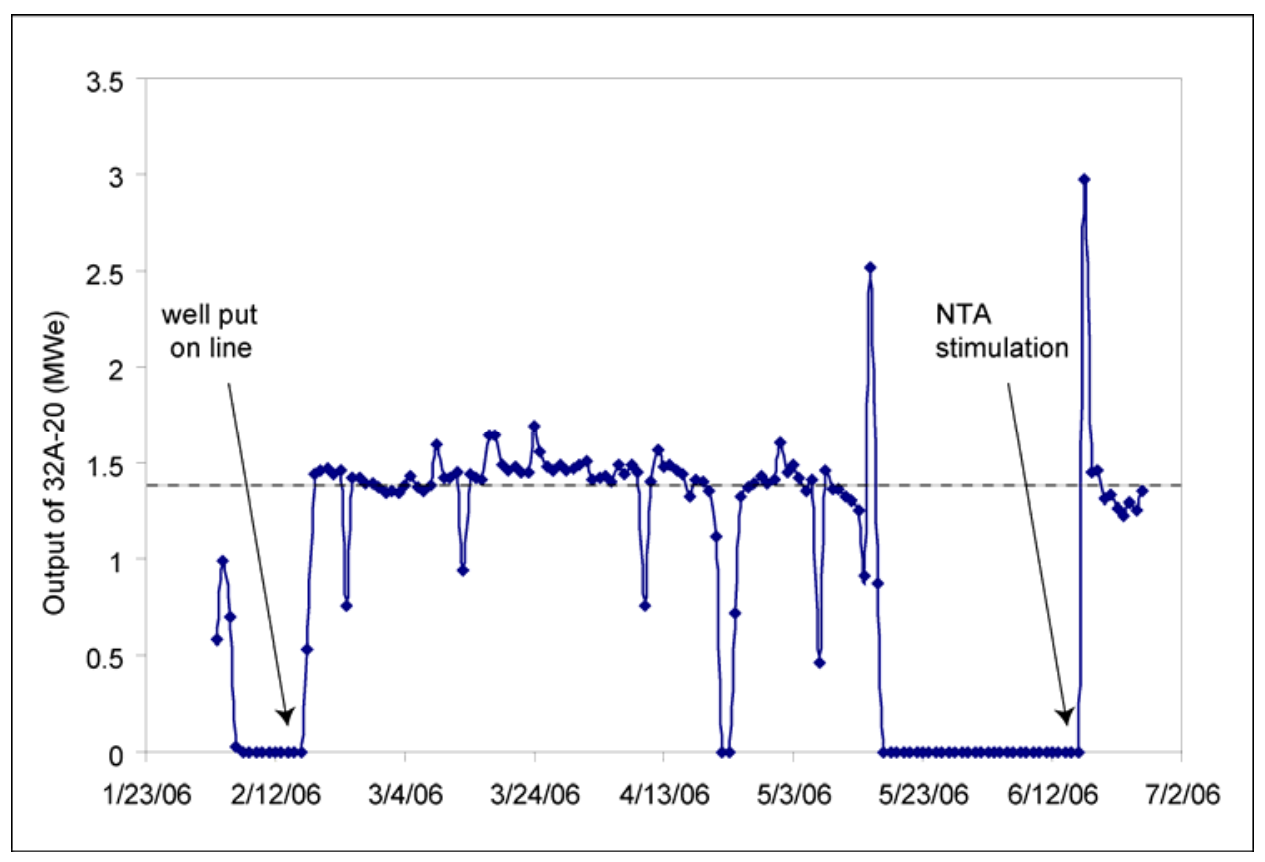

Figure 20. The output of production well 32A-20 during 2006. The well was on line between February and May when it failed. The injection of a solution of NTA restored the well nearly to the earlier production level of approximately 1.4 MWe.

Table 3 compares the NTA calcite-dissolution experiment with the more conventional approach using the strong mineral acid $\mathrm{HCl}$. As described previously, if injected from the surface, $\mathrm{HCl}$ solutions are likely to be less effective, since they flow into the formation at the first major fracture, leaving the larger portion of the wellbore untreated. Likewise, they require the use of corrosion inhibitors to prevent the dissolution of the steel in the wellbore casing. With slower calcite-dissolution kinetics, however, NTA treatments are more likely dissolve calcite more evenly along the wellbore.

Table 3. Comparison between various parameters and costs for calcite dissolution experiments using NTA and $\mathrm{HCl}$.

\begin{tabular}{|c|c|c|c|c|}
\hline $\begin{array}{c}\text { Calcite } \\
\text { Dissolution } \\
\text { Agent }\end{array}$ & $\begin{array}{c}\text { Moles of } \\
\text { Dissolution } \\
\text { Agent } \\
\text { Used }\end{array}$ & $\begin{array}{c}\text { Effective } \\
\text { Number of } \\
\text { Moles } \\
\text { Used }\end{array}$ & $\begin{array}{c}\text { Corrosion } \\
\text { Inhibitor } \\
\text { Required? }\end{array}$ & $\begin{array}{c}\text { Total } \\
\text { Cost }\end{array}$ \\
\hline \hline NTA & 20,100 & 30,200 & no & $\$ 40,000$ \\
\hline $\begin{array}{c}\text { HCl in a } \\
\text { "typical" } \\
\text { acid job }\end{array}$ & 667,000 & 667,000 & yes & $\$ 100,000$ \\
\hline
\end{tabular}


Table 3 shows that the use of NTA can be more cost effective, when the entire test costs are compared. Much less NTA was used, however, on a molar basis than $\mathrm{HCl}$ in a typical acid job. There are indications that not sufficient NTA was used and/or that not sufficient reaction time was allowed. Further testing is required to optimize the NTA calcite-dissolution approach before a true cost comparison can be made.

\section{Reactive Transport Modeling of the Benchtop Flow Reactor}

\section{$\underline{\text { Calcite Dissolution Simulations }}$}

In addition to simulating mineral dissolution and precipitation processes within the Coso reservoir, TOUGHREACT is being used to simulate mineral dissolution experiments performed by the laboratory benchtop flow reactor. Initially, the flow reactor was modeled using five layers: 4 sublayers consisting of the Texas limestone, and an empty layer allowing flow around the outside of the limestone rod. However, laboratory experimental conditions were modified to allow flow only through the limestone rod. Currently, the model setup has been changed to reflect this change in laboratory conditions. The new model setup consists of a one-layer approach with all flow being conducted through the limestone rod (Figure 21). This model has been used to simulate conditions of low-pH HCl solution as the injection fluid, and also to simulate experiments using solutions containing the chelating agent NTA (nitrilotriacetic acid) as the injectant. This model will continue to be used to study the effects of various chemical strategies on dissolution of calcite and, in the future, on $\mathrm{SiO}_{2}$.

In the past quarter, thermodynamic and kinetic data on the chelating agent NTA was input into TOUGHREACT. This data was incorporated to allow 1-D simulations representing flow of NTA solutions through the benchtop flow reactor. Sensitivity studies were undertaken to examine varying flow rates, varying $\mathrm{pH}$, and varying concentrations of NTA. In the future, these and future results will be compared with the experimental laboratory results, allowing for accurate calibration of the model. Also this quarter, lithologic, petrographic, and mineralogic data from the petrologic and petrographic studies are being input into a model to simulate injection into well 46A-19RD. Thermal and geochemical data from this portion of the field is also being incorporated into the model.

Our conceptual model considers a one dimensional flow tube simulating flow through the benchtop reactor as shown in Figure 21. The laboratory experiments were conducted under isothermal conditions $\left(21^{\circ} \mathrm{C}-204^{\circ} \mathrm{C}\right)$ and at atmospheric pressure. As in the bench top experiments, a constant injection rate was specified. The control case injection rate was 1 $\mathrm{ml} / \mathrm{min}$, but this value can be changed in the model to match any experimental conditions. The simulations were run for a total time of 1.5 days. Changes in fluid $\mathrm{pH}$, porosity, permeability, and changes in mineral abundance were monitored over the entire length of the rod over time. Mineral abundance changes were reported in terms of moles of calcite $/ \mathrm{m}^{3}$ dissolved as a function of distance along the limestone rod. Changes in porosity were calculated as a function of mineral dissolution and/or precipitation. Porosity increases indicated that mineral dissolution is dominant in these experiments. Changes in permeability were calculated from changes in porosity (Xu et al., 2004). 


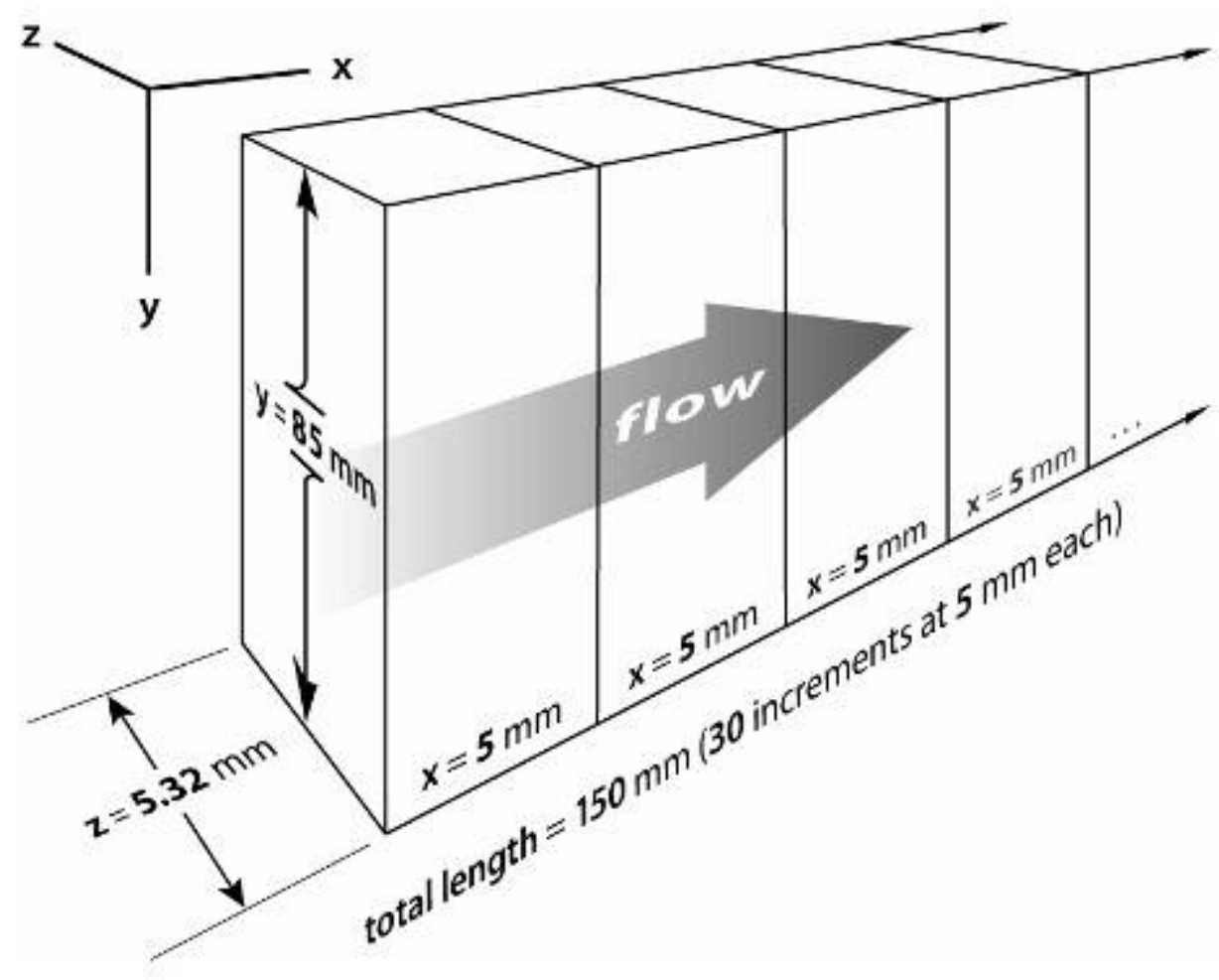

Figure 21. Geometric setup of the current one-dimensional flow reactor model.

Conditions from the flow reactor experimental run results using de-ionized water, hydrochloric acid solution, and NTA solution were input into the model. The initial model results using deionized water showed that virtually no precipitation or dissolution of the limestone rod occurs, as would be expected.

Several simulation runs were completed using hydrochloric acid $(\mathrm{HCl})$ solution as in the laboratory experiments. The 'control' case was considered to be at a $\mathrm{pH}$ of 4 and injection rate of $1 \mathrm{ml} / \mathrm{min}$. First, runs were completed varying the $\mathrm{pH}$ of the fluid between 4 and 6 . The graph displaying dissolution in moles/m3 versus distance from the injection point for the limestone rod is shown in Figure 22. From this graph, it is evident that the amount of calcite dissolution varies inversely with $\mathrm{pH}$, as expected. Also, dissolution occurs to a greater degree nearer the injection end of the reactor.

Simulations were also done keeping the $\mathrm{pH}$ constant at 4 while changing the injection rate from $0.1 \mathrm{~mL} / \mathrm{min}$ up to $10 \mathrm{~mL} / \mathrm{min}$. The graph displaying dissolution in moles $/ \mathrm{m} 3$ versus distance from the injection point for the limestone rod is shown in Figure 23. From this graph, it is evident that the amount of calcite dissolution varies directly with the flow rate, as would be expected. Also, dissolution occurs to a greater degree in the near the injection point.

Several simulations were also run using $19 \mathrm{ppm}$ NTA, high $\mathrm{pH}$ solution as the injected fluid (comparable to the laboratory experiments). Simulations varying $\mathrm{pH}$, injection rate, and concentration of NTA were performed. Graphs displaying the amount of calcite dissolution versus distance for these scenarios are shown in Figures 24-26. Both flow rate and concentration 
of NTA play a greater role than $\mathrm{pH}$ in affecting calcite dissolution. In the plot of calcite dissolution versus distance over varying flow rates, we see that the amount of calcite dissolution varies directly with flow rate. When the concentration of NTA in solution is varied, we also see a direct relationship with amount dissolved. In the case of varying $\mathrm{pH}$ (Fig. 24), the amount of calcite dissolved at $\mathrm{pH} 10$ versus $\mathrm{pH} 12$ is virtually the same.

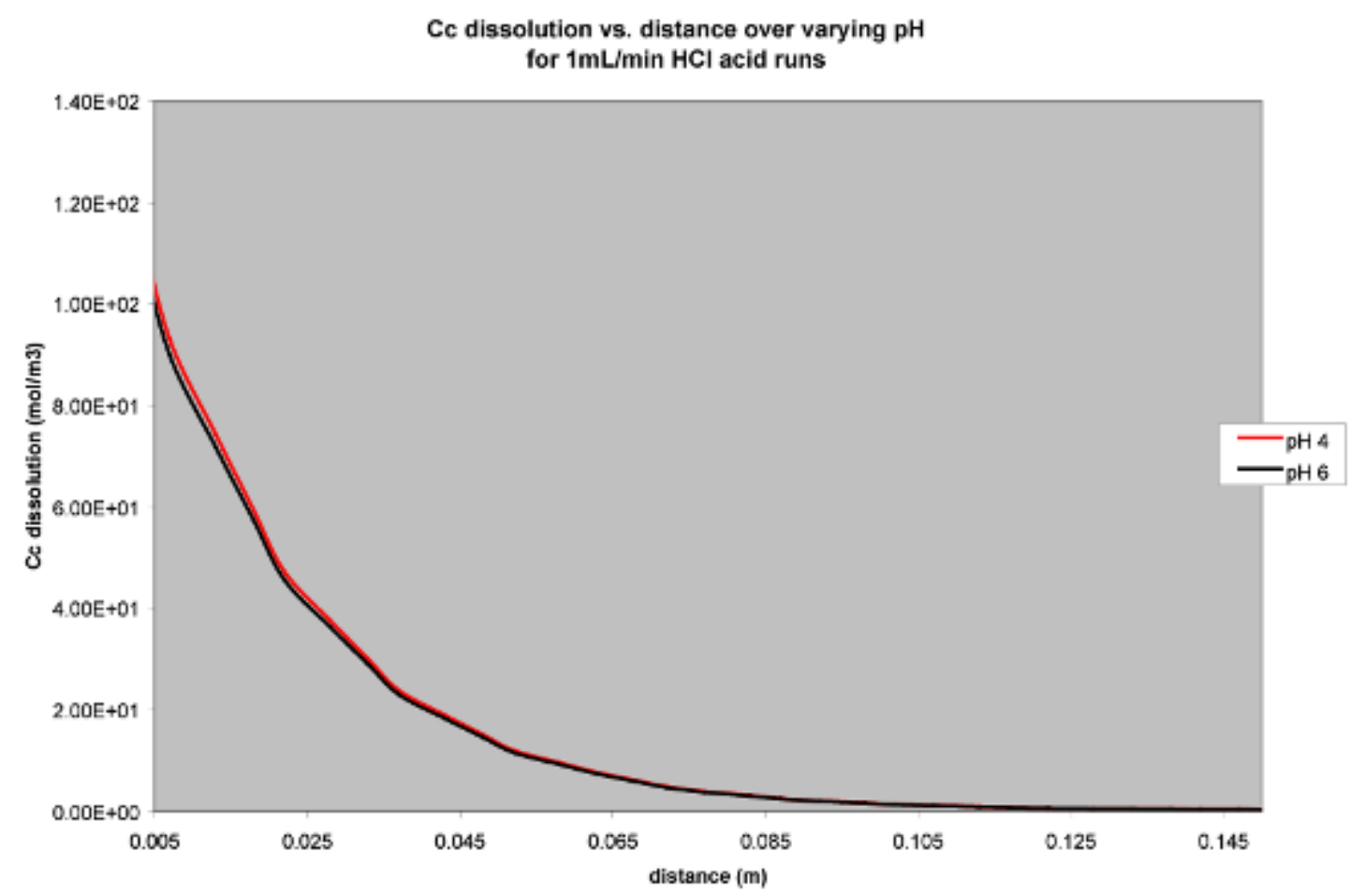

Figure 22. Calcite dissolution versus distance from the injection point over varying $\mathrm{pH}$ for the

$\mathrm{HCl}$ acid runs. See text for discussion. 


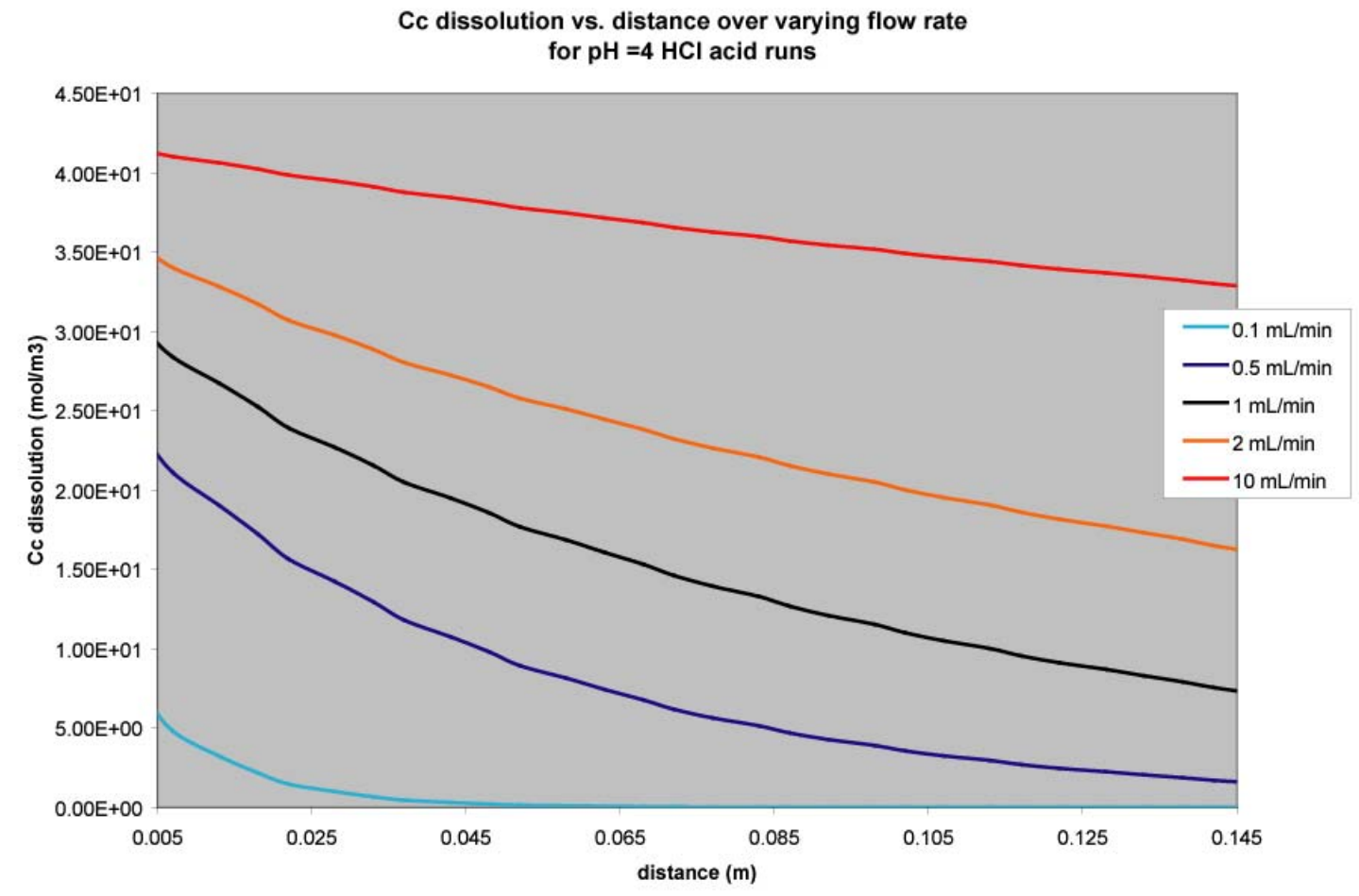

Figure 23. Calcite dissolution versus distance over varying flow rates from the injection point for the HCl acid runs. See text for discussion.

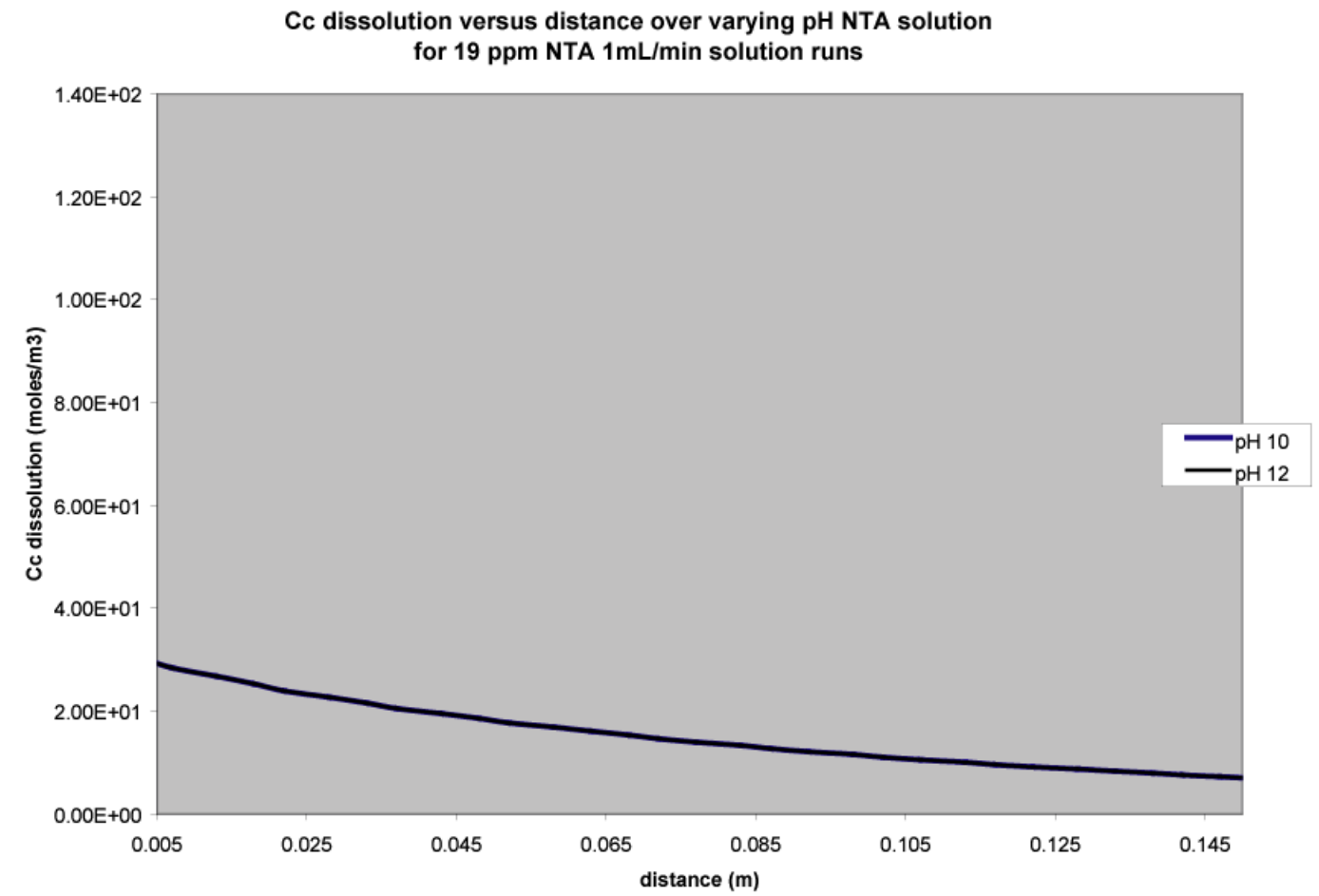

Figure 24. Calcite dissolution versus distance from the injection point over varying $\mathrm{pH}$ for the NTA solution runs. See text for discussion. 


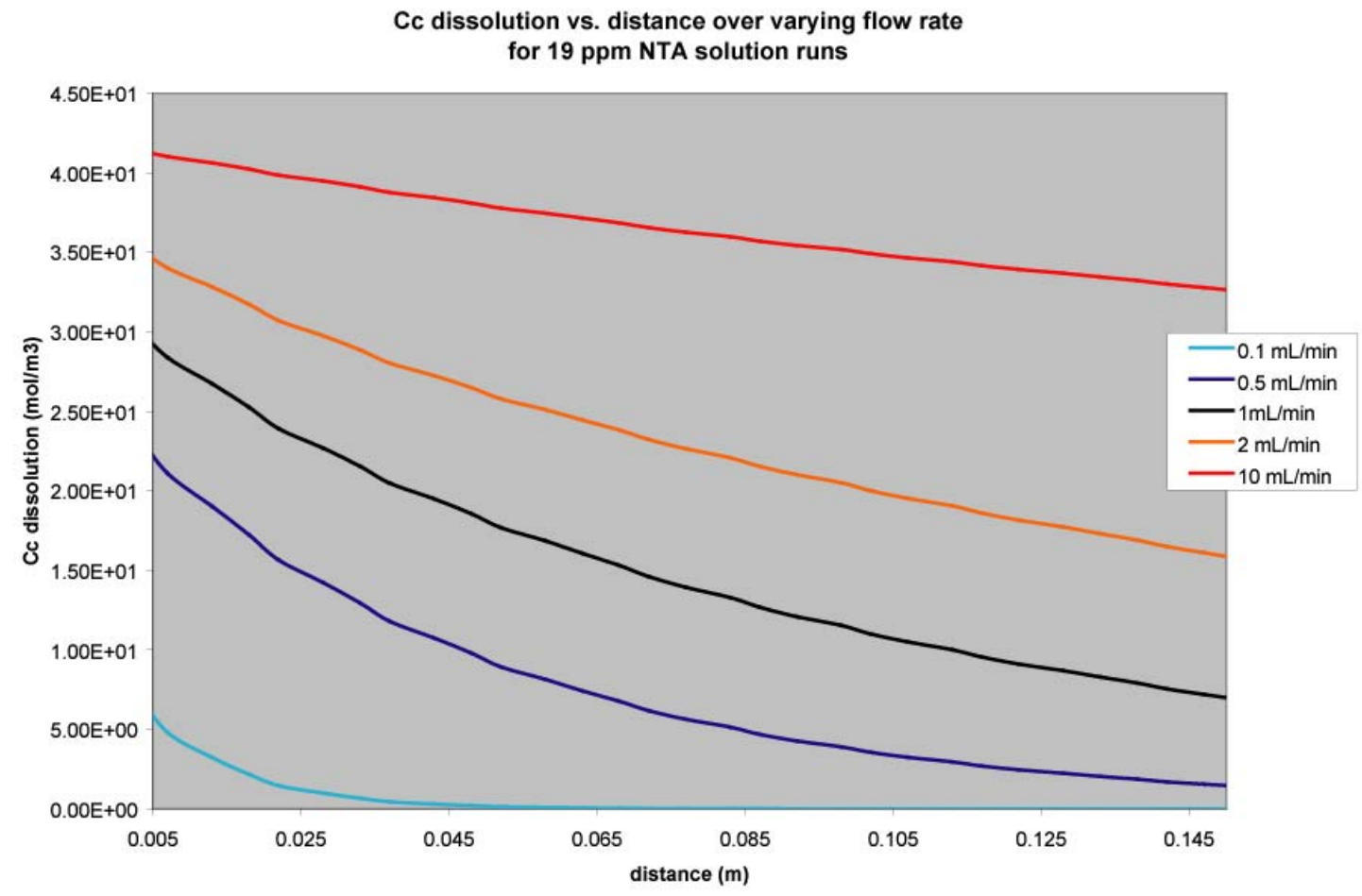

Figure 25. Calcite dissolution versus distance over varying flow rate for the NTA solution runs. See text for discussion.

Cc dissolution vs. distance over varying NTA concentrations at $\mathrm{pH}=12$ \& flow rate $=1 \mathrm{~mL} / \mathrm{min}$

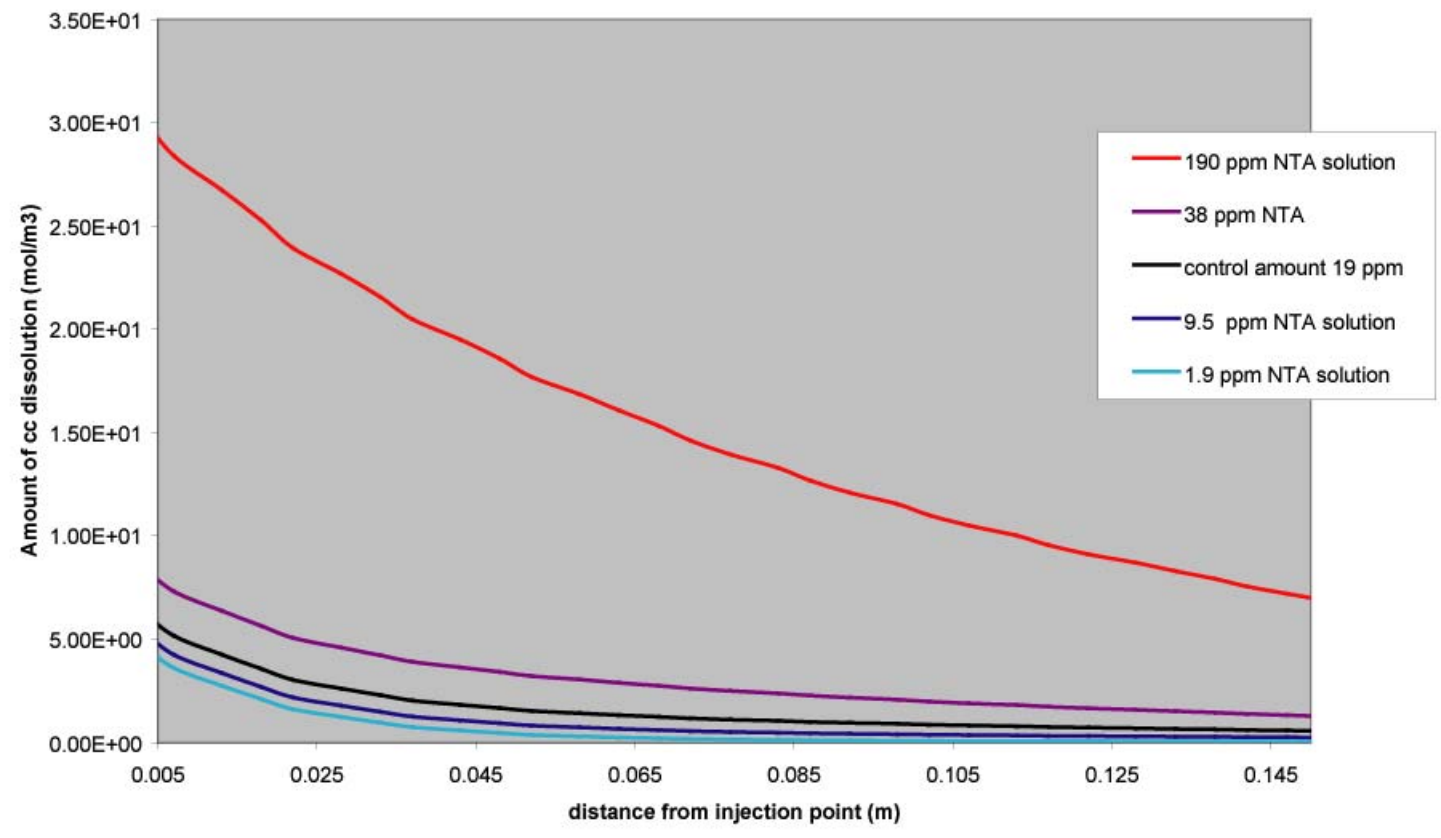

Figure 26. Calcite dissolution versus distance over varying NTA concentration for the NTA solution runs. See text for discussion. 
Figure 27 plots both the 'control' $\mathrm{HCl}$ acid solution case $(\mathrm{pH}=4,1 \mathrm{~mL} / \mathrm{min})$, and the 'control' NTA case (19 ppm NTA, $\mathrm{pH}=12,1 \mathrm{~mL} / \mathrm{min}$ ). In comparing the shape of the dissolution curves, it is evident that the acid solution creates a greater amount of dissolution near the injection point, and almost no dissolution further away. In the NTA solution case, the dissolution is more spread out over the total length of the rod.

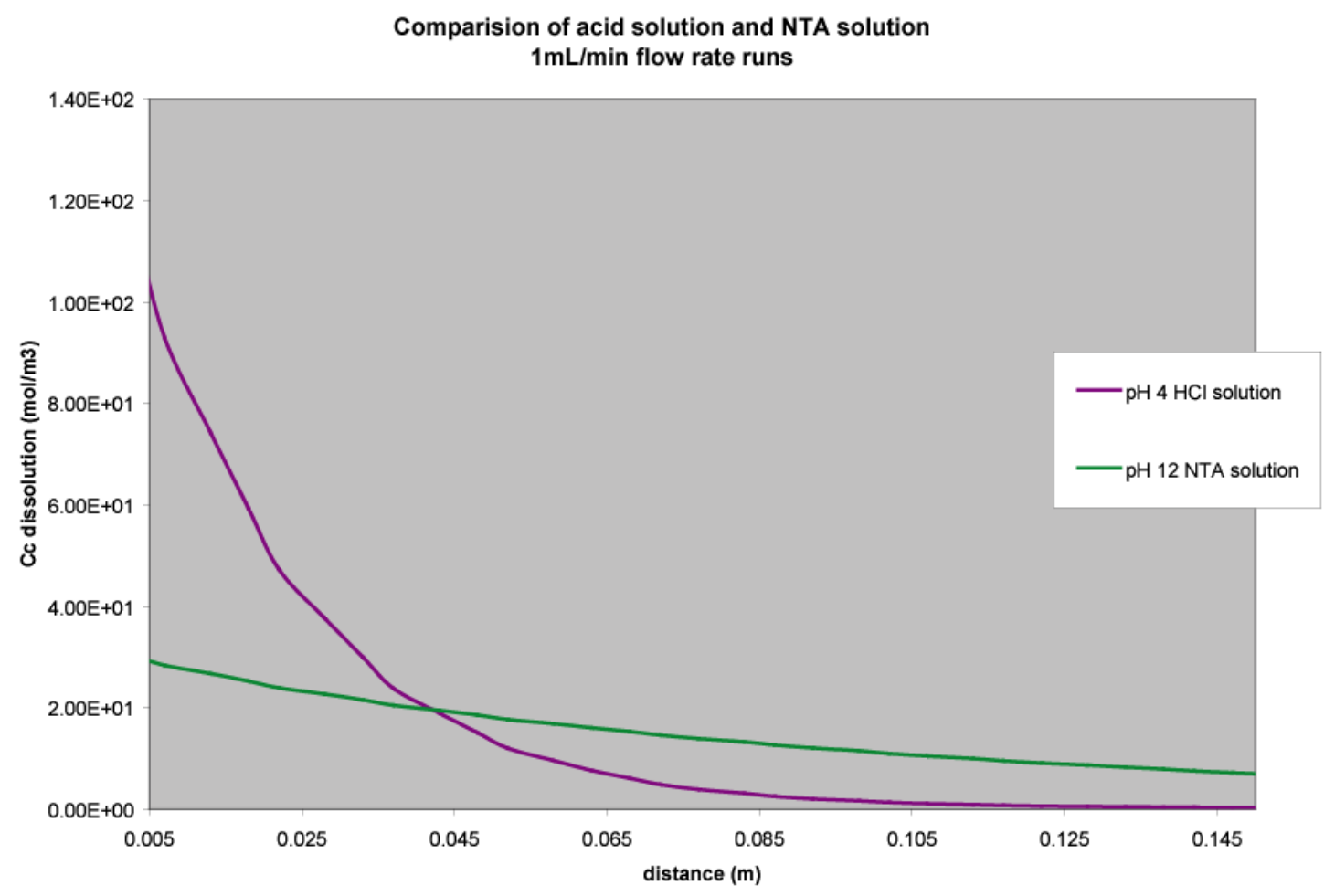

Figure 27. Comparison of the HCl and NTA 'control' case runs. See text for discussion.

\section{$\underline{\text { Silica Dissolution Simulations }}$}

Work continued with the successful laboratory-reactor simulation of the dissolution of silica in the in the presence of calcite at high $\mathrm{pH}$. The silica dissolution rate expression is critical for the successful modeling of the silica dissolution process. The following expression is used in the present work (Xu et al., 2006):

$$
r=A k_{25} \exp \left[\frac{-E_{a}}{R}\left(\frac{1}{T}-\frac{1}{298.15}\right)\right]\left(1-\frac{C}{K}\right)
$$

where $r$ is silica dissolution rate (moles per unit mineral surface area and per unit time, $\left.\mathrm{mol} / \mathrm{m}^{2} / \mathrm{s}\right)$, A is the specific reactive surface area $\left(\mathrm{m}^{2} / \mathrm{g}\right.$ mineral), $\mathrm{k}_{25}$ is the rate constant at $25^{\circ} \mathrm{C}$, $E_{a}$ is the activation energy ( $\left.\mathrm{kJ} / \mathrm{mol}\right), \mathrm{R}$ is gas constant, $\mathrm{T}$ is absolute temperature, $\mathrm{c}$ is silica concentration, and $\mathrm{K}$ is silica mineral solubility. 
Three parameters: $A, k_{25}$, and $E_{a}$, are needed using rate expression (1). Total amounts of silica dissolved during 2 hours of experiments for temperatures of 150, 200, 250 and $300^{\circ} \mathrm{C}$, were measured in the laboratory experiments (see Figure 28). The parameters in the rate expression Eq. (1) can be obtained by calibrating measured data. We assumed reactive surface area $\mathrm{A}=$ $1.31 \times 10^{-2} \mathrm{~m}^{2} / \mathrm{g}$ because $A$ and $\mathrm{k}_{25}$ are related by the product term in Eq. (1). Therefore, only $\mathrm{k}_{25}$ and $E_{a}$ need to be calibrated. Four simulations corresponding to four temperatures were performed. The simulated total amounts of silica are made to match measurements by adjusting values of $\mathrm{k}_{25}$ and $\mathrm{E}_{\mathrm{a}}$ (trial and error method).

The resulting match (see Figure 28) was obtained using $\mathrm{k}_{25}=5.64 \times 10^{-8} \mathrm{~mol} / \mathrm{m}^{2} / \mathrm{s}$ and $\mathrm{E}_{\mathrm{a}}=52.5$ $\mathrm{kJ} / \mathrm{mol}$. Variation of the amount of silica dissolved with temperature is reflected by the activation energy term $E_{a}$. The calibrated $E_{a}$ value here for the silica glass is slightly smaller than $E_{a}$ values of $60.9-64.9 \mathrm{~kJ} / \mathrm{mol}$ reported by Rimstidt and Barnes (1980) for amorphous silica dissolution. The calibrated set of parameters reproduced measured amounts of silica well for temperatures ranging from 150 to $250^{\circ} \mathrm{C}$, but not well for temperatures above $250^{\circ} \mathrm{C}$. For the latter temperature range, a smaller $\mathrm{E}_{\mathrm{a}}$ value may be required.

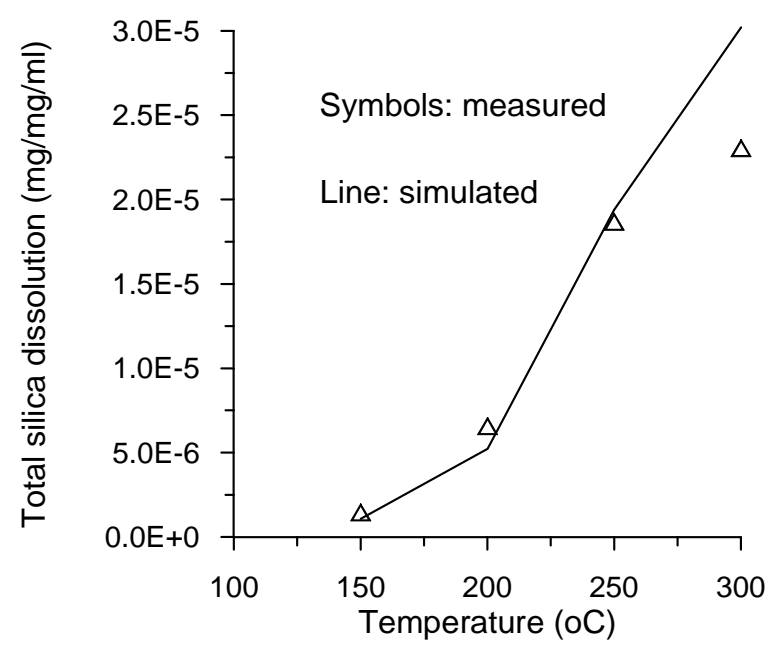

Figure 28. The simulated total amounts of silica dissolved together with measured data obtained using $k_{25}=5.64 \times 10^{-8} \mathrm{~mol} / \mathrm{m}^{2} / \mathrm{s}$ and $E_{a}=52.5 \mathrm{~kJ} / \mathrm{mol}$.

With the calibrated set of parameters, we performed numerical experiments using a temperature of $250^{\circ} \mathrm{C}$ and a range of flow rates of $2.5,5,7.5$ and $10 \mathrm{ml} / \mathrm{min}$. The simulated silica concentration and silica dissolved per unit core volume along the flow path after two hours are presented in Figures 29 and 30, respectively. Silica concentrations increase linearly, indicating that silica dissolution is kinetically-controlled and the rates are nearly constant along the flow path. The largest slope is at the lowest flow rate $(2.5 \mathrm{ml} / \mathrm{min}$, Figure 29). Increases in flow rate result in only slight increases in silica dissolution (Figure 30 ) under experimental conditions because large flow rates result in lower residence times. The kinetic control of dissolution is apparent from the fact that at the lowest rate $(2.5 \mathrm{ml} / \mathrm{min})$, less silica per unit core volume is removed near the outlet, where aqueous silica concentrations are greater, than at the inlet. If dissolution occurred subject to local equilibrium, silica dissolution should progress from the inlet to the outlet, with the advancement of the silica dissolution front proportional to total throughput of aqueous phase, i.e., proportional to flow rate. 


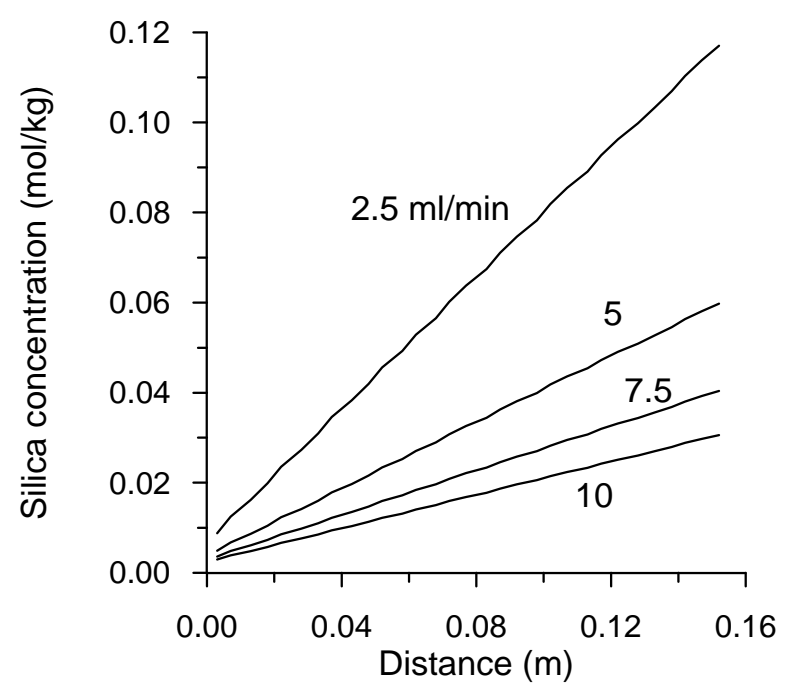

Figure 29. Simulated spatial distribution of silica concentration after two hours for different rates (at $250^{\circ} \mathrm{C}$ )

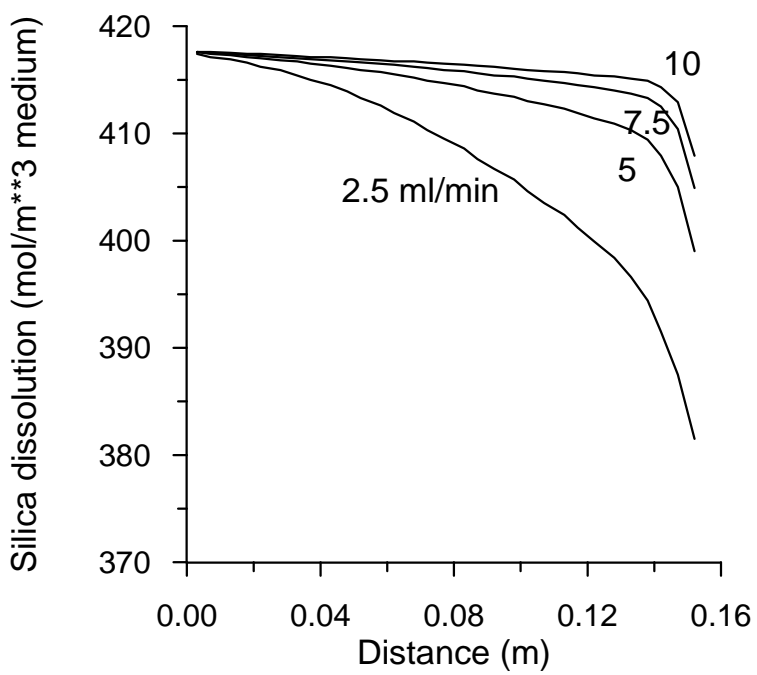

Figure 30. Simulated cumulative silica dissolved after two hours for different flow rates $\left(250^{\circ} \mathrm{C}\right)$

\section{References}

Bachler, D. (2003) "Coupled thermal-hydraulic-chemical modeling at the Soultz-sous-Forets HDR reservoir (France),” PhD dissertation, Swiss Federal Institute of Technology, Zurich, Switzerland.

Bradley, B. B., (1989) Petroleum Engineering Handbook, Society of Petroleum Engineers. 
Durst, D. (2002) “Geochemical modeling of the Soultz-sous-Forets hot dry rock test site: Coupled fluid-rock interaction to heat and fluid transport," Ph.D dissertation, Universite de Neuchatel, France.

Martell, A.E., Motekaitis, A.R., Fried, A.R., Wilson, J.S., and MacMillan, D.T. (1975) “Thermal Decomposition of EDTA, NTA, and Nitrilotrimethylenephosphonic Acid in Aqueous Solution”, Can. J. Chem., 53, pp. 3471-3476.

Mella, M., Rose, P.E., Kovac, K., Xu, T., Pruess, K., and McCullough, J., (2006) Calcite Dissolution in Geothermal Reservoirs Using Chelants: GRC Transactions, San Diego, California.

Rimstidt, J.D., and Barnes, H.L. (1980), “The kinetics of silica-water reactions,” Geochimica and Cosmochimica Acta, 44, 1683-1699.

Xu, T. and Pruess, K. (2001), "Modeling Multiphase Non-Isothermal Fluid Flow and Reactive Geochemical Transport in Variably Saturated Fractured Rocks,” Methodology, Amer. Jour. Sci., 301, pp. 16-33.

Xu, T., E.L. Sonnenthal, N. Spycher, and K. Pruess, (2006), “TOURGHREACT: A simulation program for non-isothermal multiphase reactive geochemical transport in variably saturated geologic media”, Computer \& Geoscience, 32, pp. 145-165. 